\title{
Precipitation of dolomite from seawater on a Carnian coastal plain (Dolomites, northern Italy): evidence from carbonate petrography and $\mathrm{Sr}$ isotopes
}

\author{
Maximilian Rieder ${ }^{1}$, Wencke Wegner ${ }^{2}$, Monika Horschinegg $^{2}$, Stefanie Klackl ${ }^{1}$, Nereo Preto ${ }^{3}$, Anna Breda ${ }^{3}$, \\ Susanne Gier ${ }^{1}$, Urs Klötzli ${ }^{2}$, Stefano M. Bernasconi ${ }^{4}$, Gernot Arp ${ }^{5}$, and Patrick Meister ${ }^{1}$ \\ ${ }^{1}$ Department of Geodynamics and Sedimentology, University of Vienna, Althanstr. 14, 1090 Vienna, Austria \\ ${ }^{2}$ Department of Lithospheric Research, University of Vienna, Althanstr. 14, 1090 Vienna, Austria \\ ${ }^{3}$ Department of Geosciences, University of Padua, Via Gradenigo 6, 35131 Padua, Italy \\ ${ }^{4}$ Geological Institute, ETH Zürich, Sonneggstr. 5, 8092 Zurich, Switzerland \\ ${ }^{5}$ Geoscience Centre, University of Göttingen, Goldschmidtstr. 3, 37077 Göttingen, Germany
}

Correspondence: Patrick Meister (patrick.meister@univie.ac.at)

Received: 17 February 2019 - Discussion started: 4 March 2019

Revised: 14 May 2019 - Accepted: 27 June 2019 - Published: 31 July 2019

\begin{abstract}
The geochemical conditions conducive to dolomite formation in shallow evaporitic environments along the Triassic Tethyan margin are still poorly understood. Large parts of the Triassic dolomites in the Austroalpine and the southern Alpine realm are affected by late diagenetic or hydrothermal overprinting, but recent studies from the Carnian Travenanzes Formation (southern Alps) provide evidence of primary dolomite. Here a petrographic and geochemical study of dolomites intercalated in a $100 \mathrm{~m}$ thick Carnian sequence of distal alluvial plain deposits is presented to gain better insight into the conditions and processes of dolomite formation. The dolomites occur as 10 to $50 \mathrm{~cm}$ thick homogeneous beds, millimetre-scale laminated beds, and nodules associated with palaeosols. The dolomite is nearly stoichiometric with slightly attenuated ordering reflections. Sedimentary structures indicate that the initial primary dolomite or precursor phase consisted largely of unlithified mud. Strontium isotope ratios $\left({ }^{87} \mathrm{Sr} /{ }^{86} \mathrm{Sr}\right)$ of homogeneous and laminated dolomites reflect Triassic seawater composition, suggesting precipitation in evaporating seawater in a coastal ephemeral lake or sabkha system. However, the setting differed from modern sabkha or coastal ephemeral lake systems by being exposed to seasonally wet conditions with significant siliciclastic input and the inhibition of significant lateral groundwater flow by impermeable clay deposits. Thus, the ancient Tethyan
\end{abstract}

margin was different from modern analogues of primary dolomite formation

\section{Introduction}

The formation of dolomite $\left(\mathrm{CaMg}\left(\mathrm{CO}_{3}\right)_{2}\right)$ under Earth surface conditions in modern and ancient environments is still a major unsolved problem in sedimentary geology. Dolomite does not precipitate from modern open-ocean water, apparently because its nucleation and growth are inhibited by a high kinetic barrier. For the same reason, the precipitation of dolomite under laboratory conditions has also been difficult (see Land, 1998), and therefore the factors that may have influenced dolomite formation throughout Earth history also remain poorly constrained. Van Tuyl (1914) discussed several competing theories for dolomite formation, one of which was the chemical theory, whereby dolomite is a primary precipitate, forming as the result of prevailing conditions within the depositional environment. In contrast, stable isotope and fluid inclusion data often indicate that massive dolomites formed due to the replacement of precursor calcium carbonate during burial diagenesis, i.e. at higher temperatures and under conditions decoupled from the ancient depositional environment. Chilingar (1956) suggested that the portion of dolomite in carbonates increases with geological age, implying replacement during burial. However, burial 
dolomitization requires a mechanism to pump large volumes of Mg-rich water through porous rock (Machel, 2004), and is not always a viable process. There is evidence that large amounts of dolomite could have formed under near-surface conditions (penecontemporaneous dolomite) at certain times in Earth's history, and several studies linked the abundance of dolomite to secular variation in seawater chemistry, with primary dolomite preferentially forming during times of "calcite seas" (Given and Wilkinson, 1987; Warren, 2000; Burns et al., 2000).

In contrast, penecontemporaneous dolomite formation seems to have prevailed in the Tethyan realm during the Triassic (Meister et al., 2013, and references therein; Li et al., 2018), in an "aragonite sea", while elsewhere dolomite was not particularly abundant (see Given and Wilkinson, 1987). In Norian shallow water dolomites of the Dolomia Principale, Iannace and Frisia (1994) measured oxygen isotope values as positive as $+3.5 \%$, suggesting formation at Earth surface temperatures, whereas dolomites from overlying Lower Jurassic units typically show oxygen isotope signatures of diagenetic overprint at burial temperature. Frisia (1994) interpreted these dolomites to be an early diagenetic replacement of precursor carbonate. In a recent study, Preto et al. (2015) suggested that the dolomites of the Carnian Travenanzes Formation (Fm.) in the Venetian Alps are primary precipitates; i.e. they precipitated directly from solution in the sedimentary environment and not by the replacement of a precursor phase during burial. This interpretation is based on high-resolution transmission electron microscope (HR-TEM) analysis, which revealed that single micron-scale dolomite crystals consist of grains with incoherent crystallographic orientation at a scale of a few nanometres (see Meister and Frisia, 2019). The nanocrystal structures were not replaced by any of the dolomite phases described by Frisia and Wenk (1993) in Late Triassic dolomites of the southern Alps; instead they are similar to dislocation-ridden $\mathrm{Mg}$-rich phases observed in dolomite from modern sabkhas and are interpreted as primary in origin (Frisia and Wenk, 1993). This finding is intriguing, not only because it is consistent with primary dolomite formation proposed by Van Tuyl (1916) and observed in many modern environments (e.g. Sabkha of Abu Dhabi: Illing et al., 1965; Wenk et al., 1993; unlithified dolomite is also mentioned in Bontognali et al., 2010; and Court et al., 2017; Deep Springs Lake, California: Jones, 1965; Clayton et al., 1968; Meister et al., 2011; Coorong lakes: Von der Borch, 1976; Rosen et al., 1989; Warren, 1990; Brejo do Espinho, Brazil; Sánchez-Román et al., 2009; Lake Acıgöl, Turkey: Balci et al., 2016; Neusiedler See, Austria: Neuhuber et al., 2015; Lake Van: McCormack et al., 2018), but also because it provides a window into ancient primary dolomite formation pathways. This finding is also consistent with recent experiments by Rodriguez-Blanco et al. (2015), demonstrating a nanocrystalline pathway of dolomite nucleation and growth. Critically, nanometre-size nuclei show a different surface energy landscape compared to macroscopic crystals, allowing for potentially lower energy barriers, perhaps modified by organic matter, microbial effects, clay minerals, or particular water chemistry, and thus promoting the spontaneous precipitation of dolomite.

The interpretation of primary dolomite in the Travenanzes Fm. needs further validation by nano- and atomic-scale analyses and further petrographic and geochemical investigations to establish the sedimentary and geochemical conditions in the depositional environment, an extended mud plain that occurred along the western Tethys margin during the Carnian. In particular, the origin of ionic solutions conducive to dolomite formation is still unclear. Comparison with modern environments shows that ionic solutions may either be seawater-derived, as shown for the sabkhas along the Persian Gulf coast, where several hydrological mechanisms have been discussed (Adams and Rhodes, 1960; Hsü and Siegenthaler, 1969; McKenzie et al., 1980, McKenzie, 1981; see Machel, 2004, for an overview; see also Teal et al., 2000), or derived from continental groundwater, as shown for the coastal ephemeral lakes of the Coorong area (Australia; Alderman and Skinner, 1957; Von der Borch et al., 1975; Rosen et al., 1989; Warren, 1990). While both types of fluid become concentrated during evaporation and are, perhaps, modified by the precipitation of carbonates and evaporites, it remains unclear which source prevailed during deposition of the Travenanzes Formation.

Dolomites occur in the Travenanzes Fm. as intercalated beds in a $100 \mathrm{~m}$ thick sequence of red and green clay. The environment hence differed from modern analogues (e.g. sabkhas) in that it contained large amounts of clay derived from riverine input and deposited on a distal alluvial plain, implying seasonally wet conditions. Except for the horizons containing marine fossils, this facies association shows a striking similarity to the Germanic Keuper, which represents an entirely continental playa lake system, and also exhibits intercalations of primary dolomite in red clay (Reinhardt and Ricken, 2000). The Keuper facies association extended over much larger areas than just the Germanic basin during the Carnian. Although the Travenanzes Fm. is clearly located, palaeogeographically, in the Tethyan depositional region (Breda and Preto, 2011), its facies separation from the Germanic Keuper may not be precisely coincident with palaeogeographic features, such as the Vindelician high zone. We suggest that the composition and origin of ionic solutions conducive to primary dolomite formation, from either continental water or seawater, are also an indication of separation between the two palaeogeographic domains.

Here we provide a detailed investigation of dolomites of the Travenanzes Fm. to reconstruct the processes and factors conducive to dolomite formation. We specifically searched for sedimentary structures indicating that the initial authigenic dolomite (or a precursor carbonate phase) was unlithified, as would be expected if it spontaneously precipitated from the shallow water bodies of ephemeral lakes or tidal ponds. Radiogenic Sr-isotope ratios $\left({ }^{87} \mathrm{Sr} /{ }^{86} \mathrm{Sr}\right)$ were 
measured in the dolomites and compared with the established Triassic seawater Sr-isotope curve (Veizer et al., 1999; McArthur et al., 2012) to determine if ionic solutions conducive to dolomite formation were derived from seawater or from continental runoff. To demonstrate the contrasting origin of ionic solutions, Sr-isotope values were compared to values from dolomites from the Germanic Keuper, which are of clear continental origin, and to values in modern dolomites showing marine and/or continental influence. Based on new insights, we discuss possible scenarios of dolomite formation that could have prevailed along the western Tethys margin and in similar evaporative environments.

\section{Geological setting}

The Dolomite Mountains (Southern Tyrol and Venetian Alps; Fig. 1a) are well known for their characteristic peaks consisting of Triassic carbonate platform limestones and dolomites. These platforms developed all along the margins of the western Tethys ocean (Stampfli and Borel, 2002) and were separated by deep basins in the middle Triassic and formed an extended coastal plain during the Carnian and Norian. The Adriatic plate was rotated almost $90^{\circ}$ anticlockwise as a result of the Alpine orogeny (Ratschbacher et al., 1991; Handy et al., 2010). As a result, deep-water environments are found to the north today, although they were originally located to the east (Fig. 1a). Triassic palaeogeography is largely preserved in the Dolomites in spite of Alpine deformation because the Dolomites form a ca. $60 \mathrm{~km}$ wide popup structure that is bound by the Periadriatic Line to the north and northwest and the Valsugana Fault to the southeast (Fig. 1a, inset). Therefore, the Dolomites were never buried to a greater depth, and did not experience metamorphic overprinting (Doglioni, 1987). The colour alteration index of conodonts in the Heiligkreuz Fm., which underlies the Travenanzes Fm. in this region is 1, suggesting maximum burial temperatures of less than $50^{\circ} \mathrm{C}$, which are confirmed by biomarker data (Dal Corso et al., 2012).

The Travenanzes Fm. lies unconformably above the Heiligkreuz Fm. and is overlain by the Dolomia Principale (Hauptdolomit) along a transgressive boundary (Fig. 1b). Large amounts of siliciclastic material were deposited during the Carnian, presumably as a result of a change in climate and increasingly humid episodes, and led to filling of basins that were more than $100 \mathrm{~m}$ deep that existed between the carbonate platforms of the Cassian dolomite (Gattolin et al., 2013, 2015). These basin-filling deposits formed a coastal succession or mixed carbonate-siliciclastic ramp, that includes large clinoforms made up of sandstones and conglomerates (Heiligkreuz Fm.; see Preto and Hinnov, 2003; Gattolin et al., 2013, 2015). The topography was entirely evened out and overlain by the Travenanzes Fm., a ca. $100 \mathrm{~m}$ thick and laterally extensive succession of red and green claystone with intercalated dolomites, evaporites, and siliciclastic beds

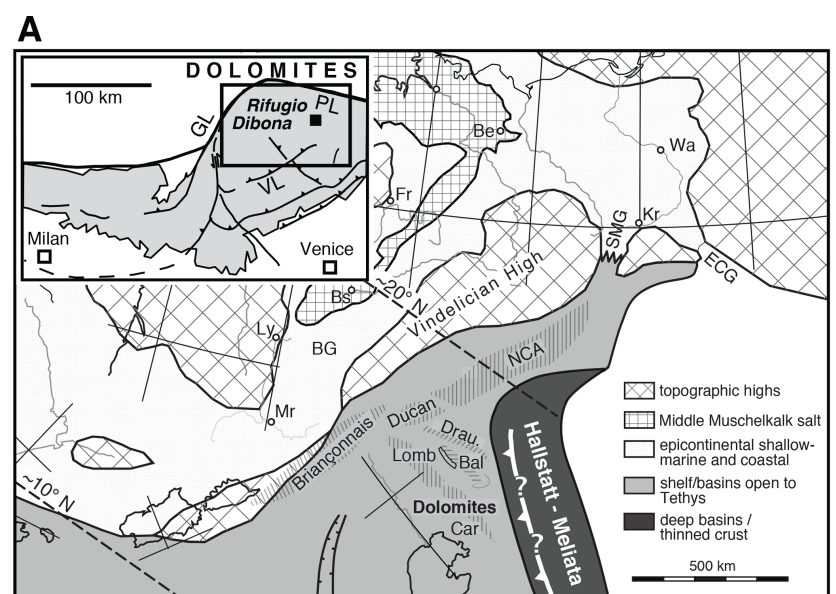

B

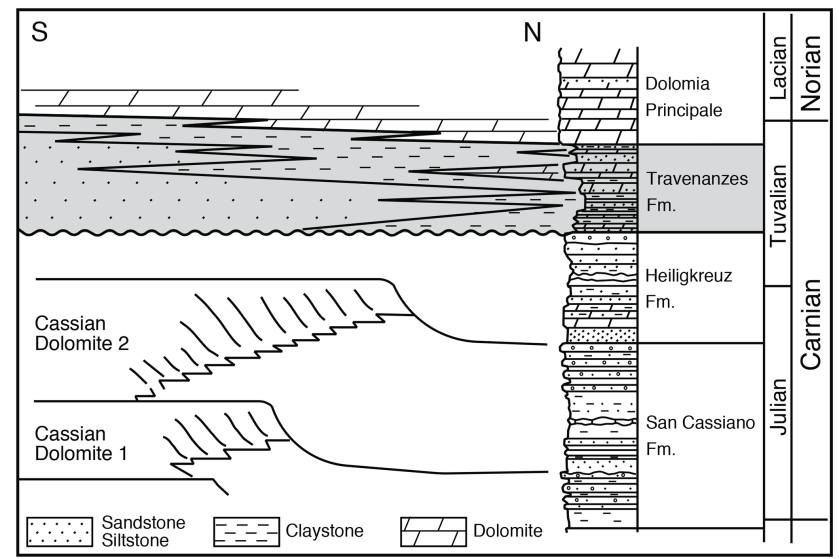

Figure 1. (a) Palaeogeographic map of southern Alpine to Germanic domains during the middle Triassic; reproduced from Brack et al. (1999; modified). Bal: Balaton; BG: Burgundy Gate; Car: Carnian Alps; ECG: eastern Carpathian Gate; Lomb: Lombardy; NCA: Northern Calcareous Alps; SMG: Silesian Moravian Gate. The following cities are indicated for orientation: Mr: Marseille; Wa: Warsaw; Kr: Kraków; Be: Berlin; Fr: Frankfurt; Ly: Lyon. Inset: tectonic map of the southern Alps (Brack et al., 1996; modified) showing the sampling location at Rifugio Dibona. GL: Giudicarie Line; PL: Pustertal Line; VL: Val Sugana Line. (b) Middle to Upper Triassic stratigraphy and distribution of facies within the Venetian Alps, showing a transition in geometries from a basin and platform topography during the lower Carnian to an extended alluvial to tidal plain in the upper Carnian. The shaded area indicates the Travenanzes Fm., showing a lateral transition in facies and a transgressive boundary with the Dolomia Principale. Compiled from Breda and Preto (2011), after De Zanche et al. (1993); modified.

(Fig. 2; Kraus, 1969; Breda and Preto, 2011). The Travenanzes Fm. shows interfingering along a south-north transect between conglomerates and sandstones to the south and carbonate-dominated peritidal to sabkha facies to the north (Breda and Preto, 2011). The upper boundary to the Dolomia Principale is time-transgressive, i.e. it becomes younger from north to south. The Travenanzes Fm. consists of three 
transgressive-regressive cycles, with the highstand deposits showing identical peritidal carbonate facies as the Dolomia Principale (Breda and Preto, 2011). The boundary with the Dolomia Principale is defined by the last occurrence of siliciclastic material (Gianolla et al., 1998).

The depositional environment of the siliciclastic facies of the Travenanzes Fm. has been interpreted as a dryland-river system by Breda and Preto (2011). Such a system occurs in arid environments if rivers drain into a coastal alluvial plain but do not reach the coast. Evaporation along the way may lead to the formation of playa lakes; on the seaward side of the system extended evaporative areas, i.e. coastal sabkhas, develop. Both types of environment are well known for giving rise to modern dolomite formation (see references above). As the southern Alps were located in tropical latitudes, a warm arid climate, perhaps influenced by a monsoon effect, developed (Muttoni et al., 2003). Rivers provided large amounts of clay, which were partially oxidized under subaerial conditions, leading to a typical red and green clay succession containing palaeosols. This facies association is widespread throughout the Alpine and Tethyan realm during the Carnian, but similar deposits are strongly deformed by Alpine tectonics in most Austroalpine units, forming a characteristic band of rauhwacke, the "Raibl beds" (e.g. Czurda and Nicklas, 1970). In the Travenanzes Fm. the entire sequence maintains its depositional architecture, providing a pristine archive to study the intercalated dolomites.

The Carnian and Norian deposits of the Keuper in the endorheic Germanic Basin contain a similar facies association as the Travenanzes Fm., but clearly represent continental playa lake deposits (Reinhardt and Ricken, 2000, and references therein). Here we consider dolomites from the Germanic Basin of confirmed continental origin for comparison of Sr-isotope compositions of continental and coastal environments.

\section{Methods}

\subsection{Petrographic and mineralogical analysis}

A total of 39 hand specimens were collected from the stratigraphic section at Rifugio Dibona, $5 \mathrm{~km}$ west of Cortina d'Ampezzo, Italy $\left(46.532727^{\circ} \mathrm{N}, 12.067161^{\circ} \mathrm{E}\right.$; Fig. 1; Breda and Preto, 2011). Additional samples of Triassic dolomites from the Germanic Basin (Weser Fm. and Arnstadt Fm. near Göttingen, northern Germany) and modern dolomite from the Coorong Lagoon (South Australia) and Deep Springs Lake (California) were also analysed for comparison. Polished thin sections were carbon coated for analysis under the scanning electron microscope (SEM) using a FEI Inspect S-50 SEM (Thermo Fisher Scientific, Bremen, Germany) at the University of Vienna. Element contents were determined semi-quantitatively using an energydispersive X-ray (EDX) detector (EDAX Ametek, New Jer- sey, United States) under high vacuum and $12.5 \mathrm{kV}$ beam voltage at a working distance of $10 \mathrm{~mm}$. Differences in mineralogy at the micron scale were mapped in backscattered electron (BSE) mode with high contrast.

For bulk mineralogical analysis, three dolomite samples were ground to a fine powder with a disk mill. Clay mineralogy was determined on $40 \mathrm{~g}$ aliquots that were leached two times for $24 \mathrm{~h}$ in $250 \mathrm{~mL}$ of $25 \%$ acetic acid to dissolve all carbonate (Hill Jr. and Evans, 1965). The clay mineral separates were washed three times with $\mathrm{H}_{2} \mathrm{O}$ and centrifuged. The grain size fraction $<2 \mu$ m was collected by sedimentation in an Atterberg cylinder after $24 \mathrm{~h} 33 \mathrm{~min}$. Oriented samples were prepared by pipetting the suspensions $(10 \mathrm{mg}$ clay/mL) on glass slides and analysed after air drying. To identify expandable clay minerals, the samples were additionally saturated with ethylene glycol and heated to $550^{\circ} \mathrm{C}$ (Moore and Reynolds, 1997). X-ray diffraction analysis of bulk samples and clay mineral separates was performed with a PANalytical X'Pert Pro diffractometer at the University of Vienna, using $\mathrm{CuK} \alpha$ radiation with $40 \mathrm{kV}$ and $40 \mathrm{~mA}$. The samples were scanned from 1.76 to $70^{\circ} 2 \vartheta$ with a step size of $0.0167^{\circ}$ and $5 \mathrm{~s}$ per step. The X-ray diffraction patterns were interpreted using the PANalytical software X'Pert High score plus and Moore and Reynolds (1997) for the clay minerals.

\subsection{Carbon and oxygen isotope analysis}

Carbon and oxygen isotopes were measured on 28 samples, which where microdrilled from thin section cuttings (see below). The samples were analysed with a Delta V Plus mass spectrometer coupled to a GasBench II (Thermo Fisher Scientific, Bremen, Germany) at ETH Zürich (Zurich, Switzerland), following the procedure described in Breitenbach and Bernasconi (2011). The precision was better than $0.1 \%$ for both isotopes. The oxygen isotope values were corrected for kinetic fractionation during dissolution of dolomite in anhydrous phosphoric acid at $70^{\circ} \mathrm{C}$, using a fractionation factor of 1.009926 (Rosenbaum and Sheppard, 1986).

\subsection{Radiogenic Sr-isotope analysis}

To ensure that $\mathrm{Sr}$ from the pure dolomite phase is extracted, specific areas free of clay minerals were defined by SEM and identified using an Olympus SZ61 microscope equipped with a MicroMill sampling system (Electro Scientific Industries). Eleven samples were drilled over an area of $5-10 \mathrm{~mm}^{2}$, or along a line in laminated rocks, to a depth of $350 \mu \mathrm{m}$. To prevent the powder from being dispersed, the samples were drilled within a drop of MilliQ- $\mathrm{H}_{2} \mathrm{O}$, and the suspension was transferred to a centrifuge tube using a pipette.

A sequential extraction was used to determine the mildest reagent that efficiently extracts the pure dolomite phase without attacking other mineral phases. The extractions were routinely performed in capped 2 or $15 \mathrm{~mL}$ polypropylene tubes at room temperature on a shaker for $10 \mathrm{~min}$ to $24 \mathrm{~h}$. The 


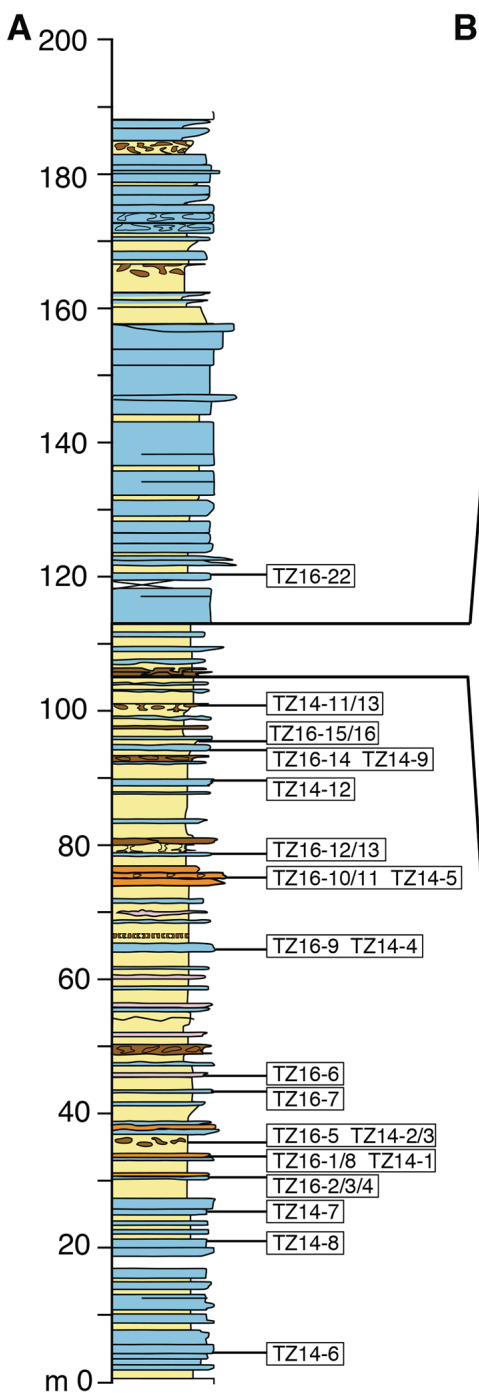

B

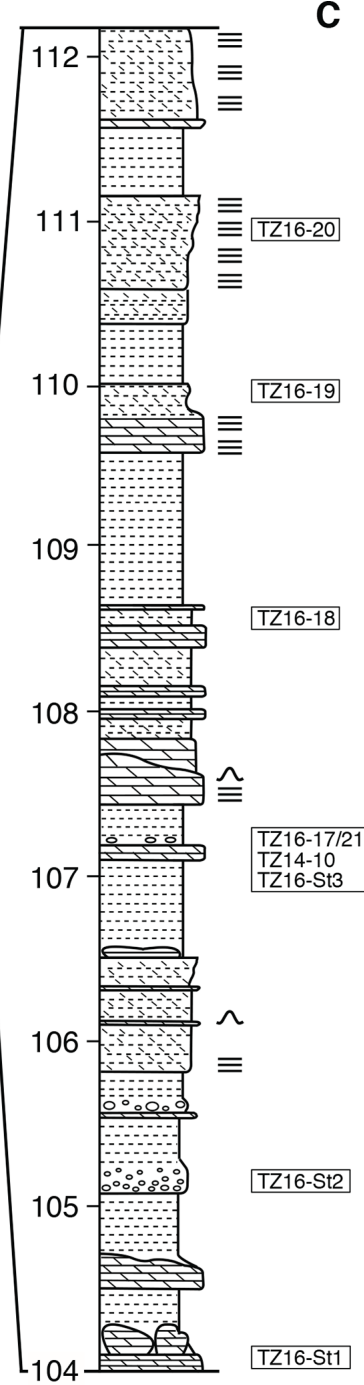

C

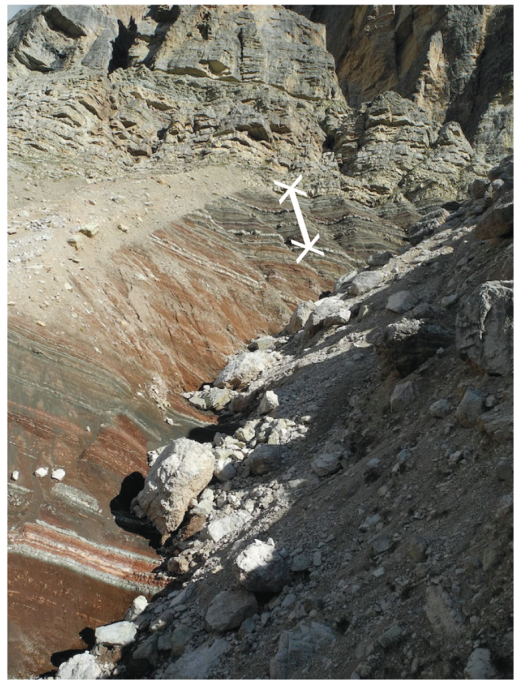

Section A

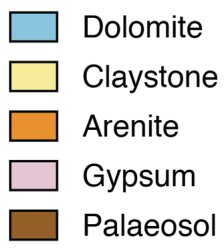

Section B

Dolomite

Claystone

Dolomite/clay interlayers

oo Dolomite nodules

$\equiv$ Lamination

$\sim$ Pseudo teepee

Figure 2. Stratigraphic section at Rifugio Dibona: (a) complete section modified after Breda and Preto (2011), showing sampling locations; (b) detailed section of the uppermost part of the clay-rich interval, showing sampling locations. (c) Outcrop photograph showing the uppermost grey part of the clay-rich interval including the location of the profile shown in (b).

following leaching reagents (always $2 \mathrm{~mL}$ ) were used: $1 \mathrm{M}$ $\mathrm{NaCl}, 3.3 \mathrm{M} \mathrm{KCl}, 0.1 \mathrm{~N}$ acetic acid, $1 \mathrm{~N}$ acetic acid, and $6 \mathrm{~N}$ $\mathrm{HCl}$. Each reaction step was repeated once, and the residues were washed with $2 \mathrm{~mL}$ of MilliQ $\mathrm{H}_{2} \mathrm{O}$ after each step to remove remains of the previous solvent.

Extraction efficiency was tested on bulk samples, clay samples, pure celestine, and barite purchased from W. Niemetz (Servitengasse 12, 1090 Vienna, Austria); pure dolomite powder from Alfa Aesar (Thermo Fisher - Kandel - GmbH, P.O. Box 1107 65, 76057 Karlsruhe, Germany) and a fragment of a single dolomite crystal (Montana; Geoprime Minerals and Earth Materials Co.) were analysed as controls. These samples were crushed to a powder in an agate mortar and pestle. Dolomite, barite, and celestine were mixed in a similar ratio as they occur in the dolomites of the Trave- nanzes Fm. and run through the entire procedure as a control of extraction efficiency; $14 \mathrm{mg}$ of rock powder was weighed out for isotope analysis. In order to rule out contamination by $\mathrm{Sr}$ from clay minerals, pure claystone of the Travenanzes Fm. was extracted separately. To ensure that clay samples do not contain carbonate, clay samples were analysed for total organic and inorganic carbon using a LECO RC-612 multiphase carbon analyser, at the Department of Environmental Geosciences at the University of Vienna, with a temperature ramp of $70^{\circ} \mathrm{C}$ per min to a maximum temperature of $1000^{\circ} \mathrm{C}$.

Total element concentrations were measured in leachates of three dolomite specimens previously analysed by XRD and the two claystones. Five millilitres of each fraction was used for element concentration analysis (the rest was further 
processed for Sr-isotope analysis; see below). The solutions were evaporated on a heating plate and the residues were redissolved in $5 \mathrm{~mL} 2.5 \mathrm{~N} \mathrm{HNO}_{3}$. This step was repeated with $5 \mathrm{~mL} 5 \% \mathrm{HNO}_{3}$. Concentrations were measured with a Perkin Elmer 5300 DV ICP-OES at the Department for Environmental Geosciences (University of Vienna). Detection limits for the different elements in rock $\left(\mu \mathrm{molg}{ }^{-1}\right)$ were as follows: $\mathrm{Al}-0.185 ; \mathrm{Ca}-0.025 ; \mathrm{Fe}-0.090 ; \mathrm{K}-0.026 ; \mathrm{Mg}$ $-0.041 ; \mathrm{Mn}-0.002 ; \mathrm{Na}-0.004 ; \mathrm{P}-0.032 ; \mathrm{Ti}-0.002 ; \mathrm{Ba}-$ $0.001 ; \mathrm{Sr}-0.001 ; \mathrm{Rb}-0.012$. The precision of the measurements (relative standard deviation; RSD) for $\mathrm{Al}, \mathrm{Ca}, \mathrm{K}, \mathrm{Mg}$, $\mathrm{Ti}, \mathrm{Ba}$, and $\mathrm{Sr}$ was $\leq 0.9 \%$, and for $\mathrm{Fe}, \mathrm{Mn}, \mathrm{Na}, \mathrm{Rb}$, and $\mathrm{P}$, it was $\leq 6.8 \%$.

For $\mathrm{Sr}$-isotope measurements, $\mathrm{Sr}$ was separated from interfering ions (e.g. Fe, $\mathrm{K}, \mathrm{Rb}$, and $\mathrm{Ca}$ ) using an ion exchange column packed with BIO RAD AG 50W-X8 resin (200-400 mesh, hydrogen form). Leachates were evaporated, dissolved in $6 \mathrm{~N} \mathrm{HCl}$ and $2.5 \mathrm{~N} \mathrm{HCl}$ and loaded onto the column in $2 \mathrm{~mL} 2.5 \mathrm{~N} \mathrm{HCl}$. Next, $51 \mathrm{~mL}$ of $2.5 \mathrm{~N} \mathrm{HCl}$ were run through the column to wash out the interfering ions. $\mathrm{Sr}$ was eluted with a further $7 \mathrm{~mL} 2.5 \mathrm{~N} \mathrm{HCl}$ and dried after collection. Total procedural blanks for $\mathrm{Sr}$ were $<1 \mathrm{ng}$ and were taken as negligible (the amounts of strontium in the samples were always higher than $100 \mathrm{ng}$ ).

The isotopic composition of $\mathrm{Sr}$ was measured with a Triton (Thermo Finnigan) thermal ionization mass spectrometer at the University of Vienna. Sr fractions were loaded (dissolved in $1 \mu \mathrm{L} \mathrm{H}_{2} \mathrm{O}$ ) as chlorides and vaporized from a $\mathrm{Re}$ double filament. The double filament configuration was used to accelerate detachment of $\mathrm{Sr}$ from the filament. The cup configuration was calibrated such that masses 84,85 (centre cup), 86, 87, and 88 are detected. The NBS987 Sr-isotope standard (number of replicates $=40$ ) shows a ${ }^{87} \mathrm{Sr} /{ }^{86} \mathrm{Sr}$ ratio of $0.710272 \pm 0.000004$ during the time of investigation, with the uncertainty of the Sr-isotope ratios quoted as $2 \sigma$. Interference with ${ }^{87} \mathrm{Rb}$ was corrected using a ${ }^{87} \mathrm{Rb} /{ }^{85} \mathrm{Rb}$ ratio of 0.386. Within-run mass fractionation was corrected for ${ }^{86} \mathrm{Sr} /{ }^{88} \mathrm{Sr}=0.1194$.

\section{Results}

\subsection{Petrographic description of dolomites}

Hard cemented beds and nodules of dolomite are intercalated in a $100 \mathrm{~m}$ thick, clay-rich interval (Fig. 2), above which the facies switches sharply to massive, bedded dolomites similar to those of the overlying Dolomia Principale. Macroscopically, three types of dolomite can be distinguished: homogeneously bedded dolomite, laminated dolomite, and nodular dolomite (Fig. 3a-c). The lower and middle part of the clay-rich unit contains mainly homogeneous dolomite beds in red clay. Between 40 and $70 \mathrm{~m}$, several horizons with gypsum nodules occur (Fig. 3d). A $30 \mathrm{~cm}$ thick fluvial conglomerate with dolomite-cemented quartzarenites and pebbles of ripped-up micritic carbonate occurs at $75 \mathrm{~m}$ (Fig. 3e), above which palaeosols with decimetre-scale vertical peds, possible root traces showing green reduction haloes, and nodular dolomite (calcic Vertisols; see Cleveland et al., 2008), are more frequent (e.g. Fig. 3b). Ca. $20 \mathrm{~cm}$ thick tempestite beds with Megalodon bivalves, foraminifers, and ostracods occur at 65 and $89 \mathrm{~m}$. A pronounced transition occurs in the uppermost ca. $8 \mathrm{~m}$ of the clay-rich interval (Fig. 2b), where the clay entirely changes from a red to a grey colour (Fig. 2c), and laminated dolomites become dominant, while evaporites and palaeosols are absent. The laminated dolomites (Fig. 3c) and centimetre- to decimetre-scale dolomite-clay interlayers show intense slumping and soft sediment deformation and pseudo-teepee structures (Figs. 3f, g). A short summary of petrographic analyses of thin sections of the different types of dolomite including the most important features appears below and is compiled in Table S1 in the Supplement.

\subsubsection{Homogeneous dolomites}

Homogeneous dolomite beds are usually 10 to $50 \mathrm{~cm}$ thick, embedded within clays and exhibiting sharp, plane-parallel joints. The beds consist of dolomicrite, which was previously described as aphanotopic dolomite by Breda and Preto (2011), according to the extended nomenclature for dolomite fabrics by Randazzo and Zachos (1983). The sediment is matrix-supported and contains irregular, partially rounded mud clasts (intraclasts) that consist of aphanotopic dolomite. Some of the mud clasts contain smaller and somewhat darker mud clasts or peloids (Fig. 4a, arrow). Soft sediment deformation is often not clearly visible due to the homogeneous structure of the mud, but it can be observed where the mud clasts are deformed within the matrix (Fig. 4b). Some of the homogeneous beds in the lower part of the section show submillimetre lamination that is only visible under the microscope, where it consists of alternating layers of light (locally coarser) and dark aphanotopic dolomite.

The clay content in the homogeneous beds is generally low. A few beds (e.g. at $33.5 \mathrm{~m}$ in the section) consist of silty or sandy dolomite, as reflected in a high abundance of detrital quartz in thin section. Pseudomorphs after gypsum occur in a dolomite bed at $120 \mathrm{~m}$ (Fig. 4c, d). Moldic porosity occurs within aphanotopic dolomite layers at 43,65 , and $89 \mathrm{~m}$. These correspond to the tempestite beds observed in outcrop (see Breda and Preto, 2011).

One dolomite bed, located at $64 \mathrm{~m}$ in the section, appears homogeneous at outcrop scale, but consists of oolitic grainstone and lacks both an aphanotopic and a cement matrix (Fig. 4e). Ooids show concentric, micritic layers and are either hollow (where the cores may have been dissolved) or filled with sparite, and are surrounded with an isopachous cement rim. 

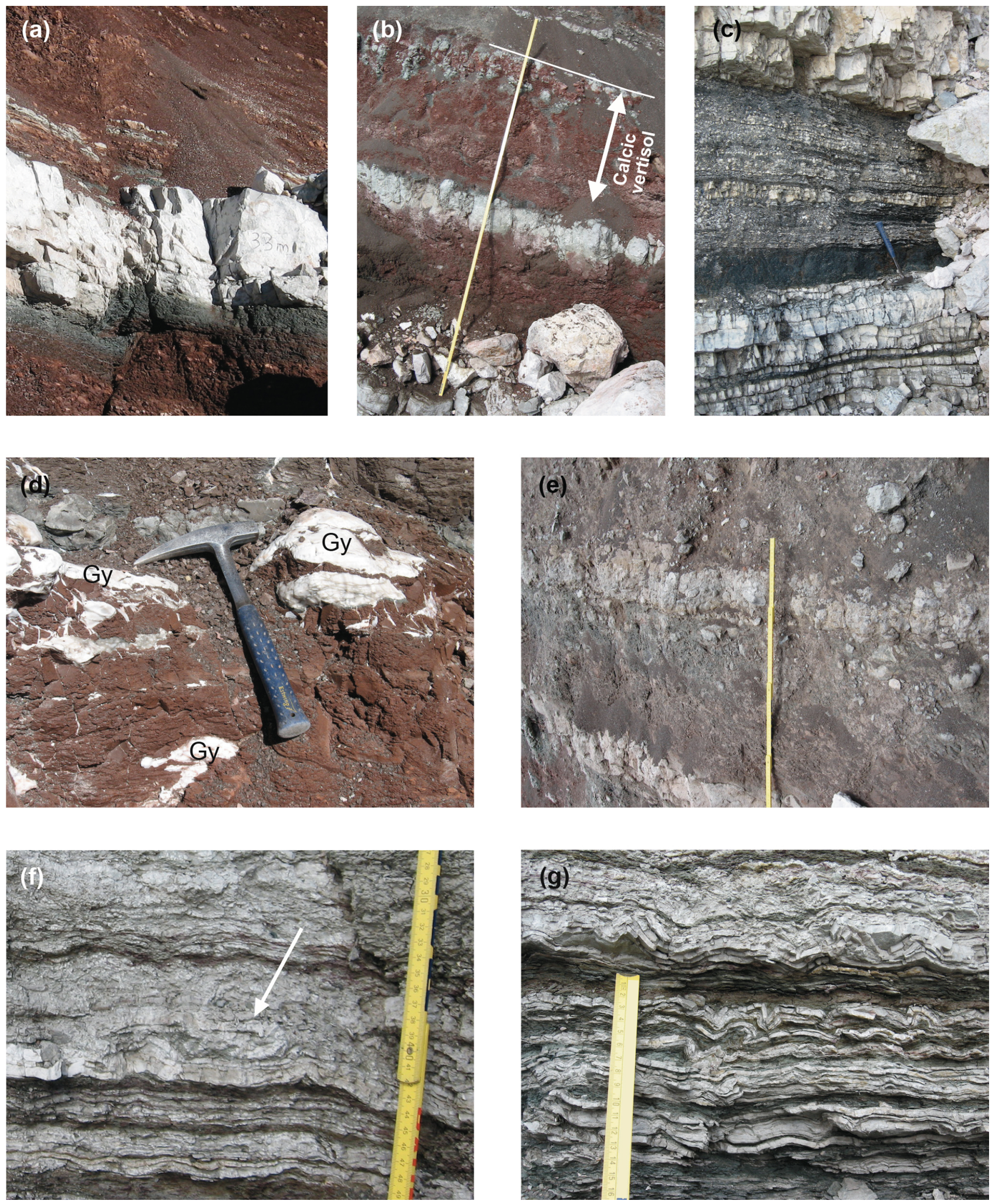

Figure 3. Outcrop images of different types of dolomite intercalated with red and grey clay of the Travenanzes Fm. at Rifugio Dibona: (a) homogeneous dolomite bed $(15 \mathrm{~cm}$ thick; $33 \mathrm{~m})$. (b) Upper part: dolomite nodules embedded in red clay, cross-cut by green-coloured cracks that are part of a calcic Vertisol (95 m). (c) Laminated dolomite (110-112 m) interbedded with grey clay. (d) Bed containing gypsum nodules (Gy), along with gypsum-filled cracks at $50 \mathrm{~m}$; (e) Dolomite-cemented conglomerate bed at $75 \mathrm{~m}$. (f) Laminated bed showing soft sediment deformation $(106 \mathrm{~m})$; an isoclinal synsedimentary fold is indicated by the arrow. (g) Laminated dolomite showing folding of the laminae due to soft sediment deformation (same bed as in $\mathbf{f}$ ). 

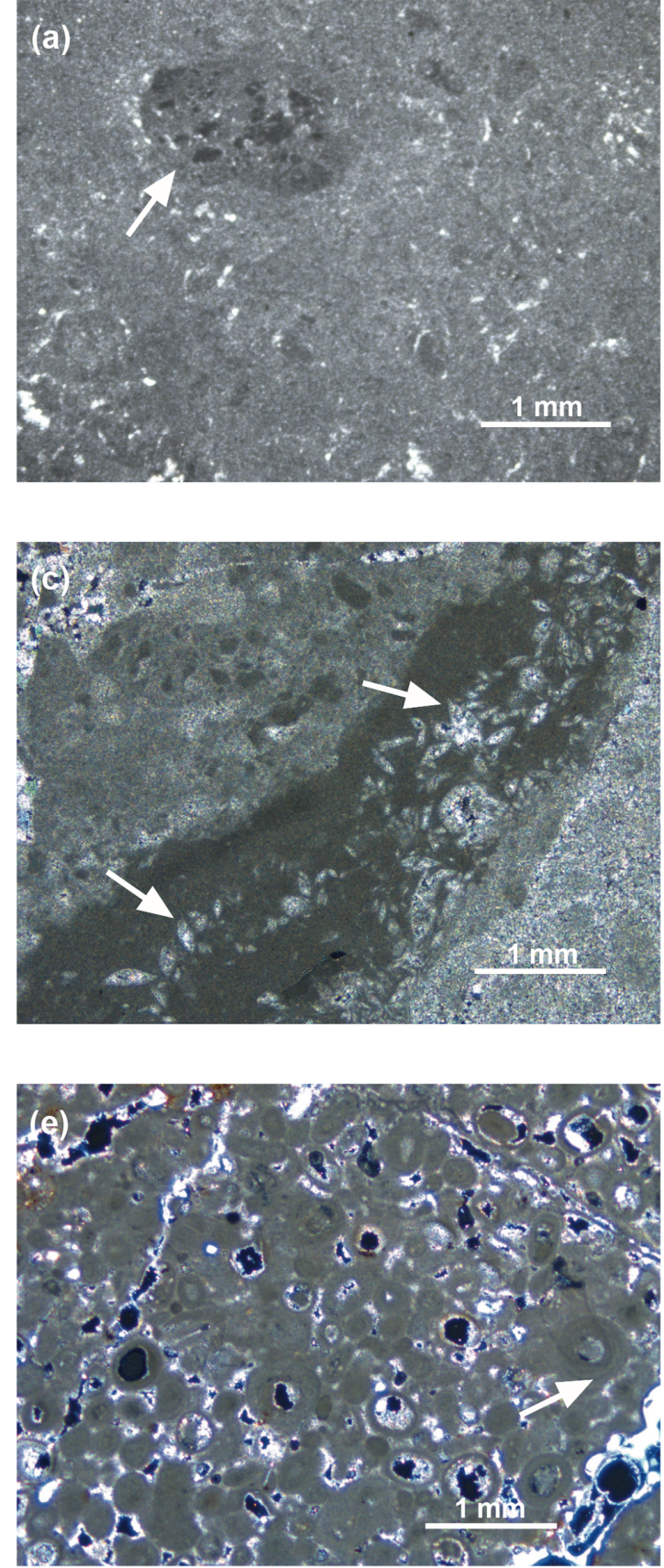

Figure 4.

\subsubsection{Laminated dolomites}

Laminated dolomites occur in the upper part of the clay-rich interval, between 90 and $110 \mathrm{~m}$ in the section (Fig. $4 \mathrm{f}-\mathrm{i}$ ). In the field, the laminated dolomites show an alternation between light grey dolomite laminae and dark grey to black clay laminae. Some dolomite laminae are bent upward and are reminiscent of pseudo-teepee structures (Fig. 4f); the space within the teepee is sometimes infilled with sparry cement. In addition, the bending of the laminae towards the
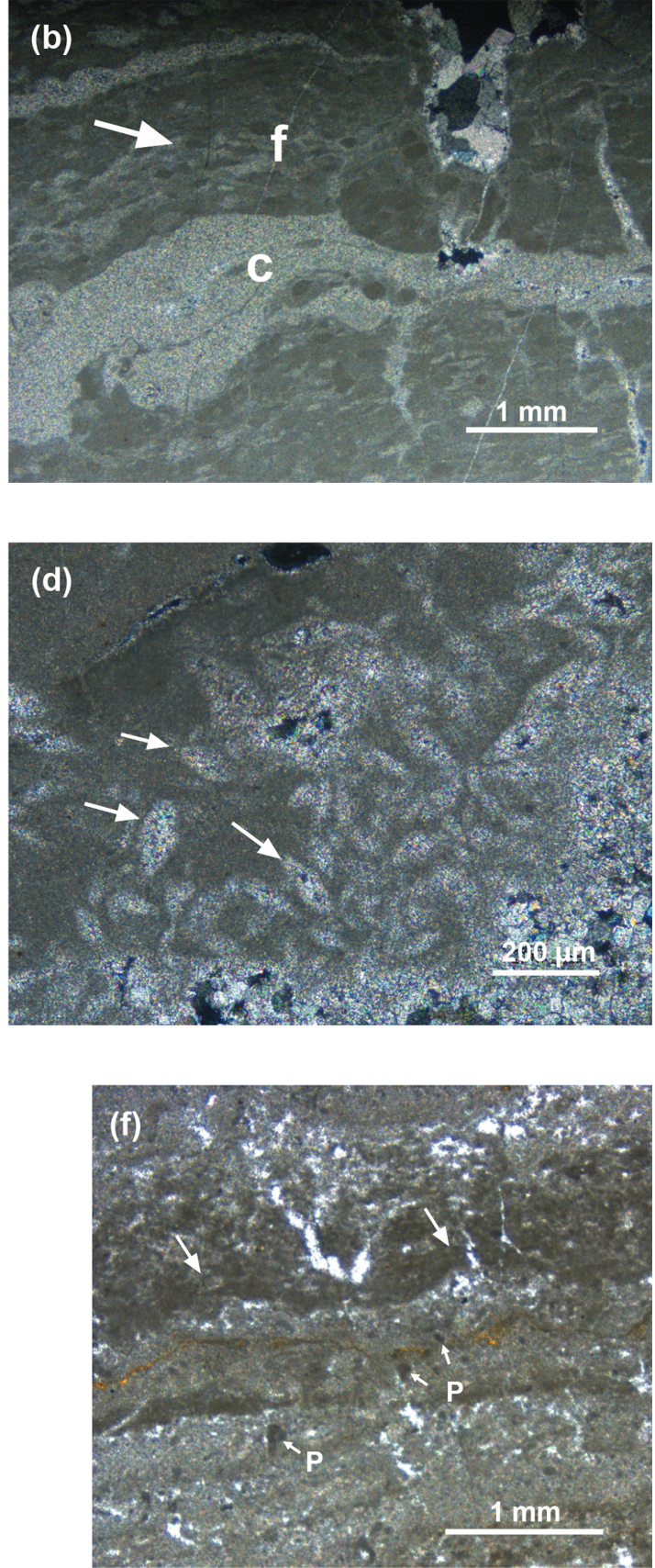

upward-directed cuspids is reminiscent of load structures (dish structures), but they may also represent desiccation cracks. The laminae are frequently ripped apart and fragments of laminae occur reworked as flat pebbles embedded in an aphanotopic dolomite matrix (Fig. 4g). Some laminae show a microsparitic appearance and laminar fenestral porosity. In some laminae a clotted peloidal fabric is observed (e.g. in Fig. 4f). Laminae are typically graded, whereby the upper part is darker, indicating an increase in the clay content (Fig. 4h, i). The top of the laminae is often truncated by an 

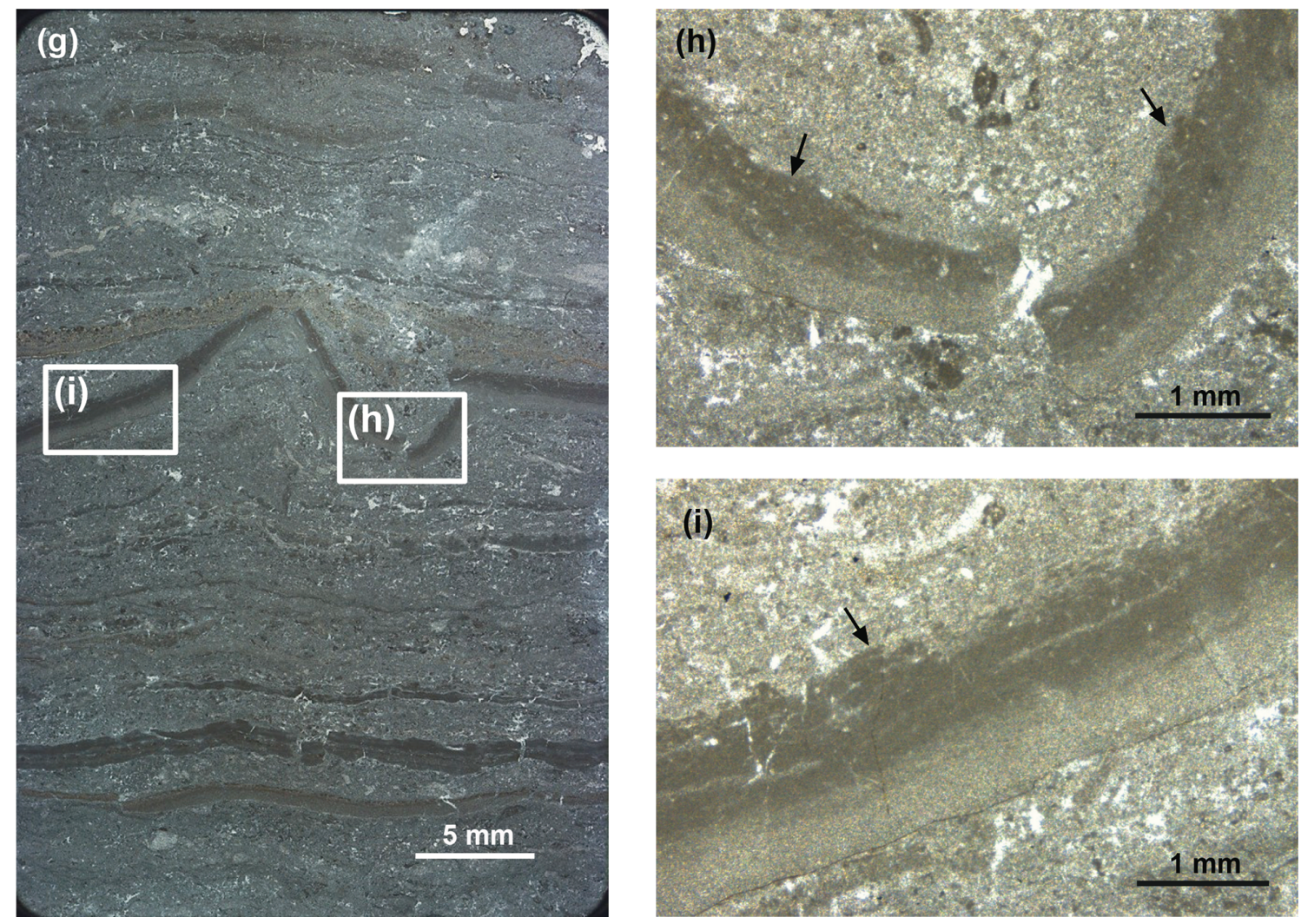

Figure 4. Photomicrographs of thin sections of dolomites of the Travenanzes Fm.: (a) rounded mud clasts embedded in dolomicrite matrix. The larger, millimetre-size intraclast in the upper left side of the image (arrow) consists itself of matrix with darker, embedded mud clasts (sample TZ16-St1; 104 m). (b) Mud clasts in dolomicrite matrix. Mud clasts are deformed (e.g. arrow); layers of coarser (c) and finer matrix (f) are equally affected by plastic deformation (sample TZ16-22; $120 \mathrm{~m}$ ). (c, d) Pseudomorphs after gypsum in fine-grained dolomudstone (e.g. arrows). (e) Oolitic grainstone (sample TZ14-4; $64 \mathrm{~m}$ ). The cortices consist of microcrystalline dolomite and lack a radial structure, some showing a concentric structure (arrow). (f) Laminated dolomite showing pseudo-teepee structures (arrow). Vertical cracks are often, but not always, associated with pseudo-teepees (sample TZ14-10; $107 \mathrm{~m}$ ). Some coarser-grained laminae may contain microsparite and peloids (P with small arrows). (g) Laminated dolomite showing both plastic and brittle deformation of laminae. A centimetre-scale pseudoteepee occurs in the centre of the image (sample TZ16-21; $107 \mathrm{~m}$ ). (h, i) Close-up of graded lamina in (g) showing plastic deformation. The top of the lamina shows an erosion surface with small rip-up clasts (arrow), overlain by a coarser layer.

erosion surface, and rip-up clasts of the fine mud are embedded in the overlying coarse layer. Some laminated dolomites contain continuous layers with inclusions of celestine crystals in the $100 \mu \mathrm{m}$ range, some of them with barite in their centre (Fig. 5a-c). Pyrite also occurs.

Under the SEM, laminated dolomites show an anhedral structure in the $1-5 \mu \mathrm{m}$ range. No difference in mineral structure and grain size is observed between mud clasts and the surrounding, often lighter-coloured matrix. Dolomite crystals at the margins between dolomite and clay interlayers often coalesce into $5 \mu \mathrm{m}$-scale, round aggregates consisting of several subhedral crystals with different orientations (Fig. 6a, $\mathrm{b}$; the crystals show orientation contrast under BSE mode). Dolomite crystals are often porous, showing a somewhat disordered appearance, but they are surrounded by syntaxial rims. In most cases, the rims entirely fill the intercrystalline space, forming almost hexagonal compromise bound- aries (Fig. 6c, d). These rims occur both in homogeneous and laminated dolomites.

\subsubsection{Nodular dolomites}

Nodular dolomites (Fig. 3b) often occur in beds of vertical peds linked to palaeosols, as indicated by horizons of vertical cracks showing green alteration fronts. Single nodules may also sporadically occur embedded within metre-thick beds of red and green clay. Nodules are usually 5 to $10 \mathrm{~cm}$ in diameter, consist of aphanitic dolomite or occasionally somewhat coarser microspar, and in cross section show both red and pale grey areas. Most nodules also show a deformed or brecciated internal structure with the interstices between the clasts mostly consisting of matrix and clay cutans. 

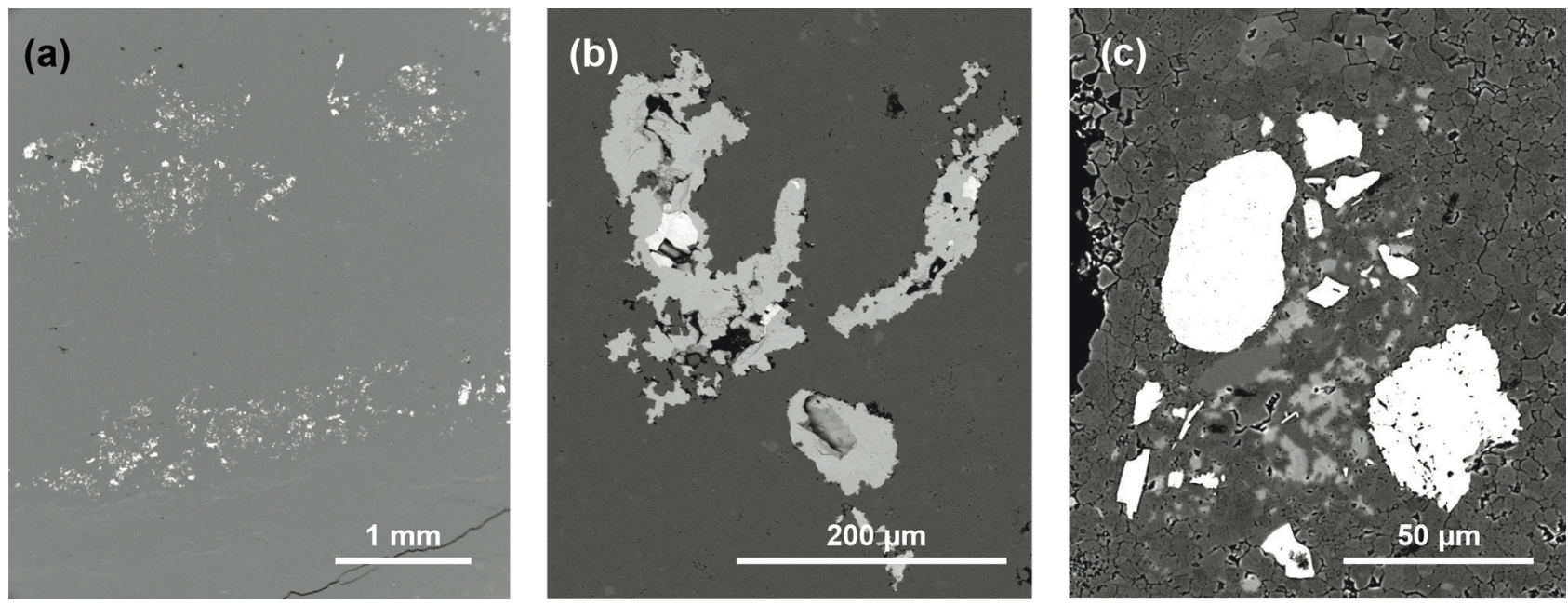

Figure 5. SEM images of dolomites in backscatter mode: (a) overview showing a dolomite layer containing celestine inclusions (bright areas; sample TZ14-9d; $95 \mathrm{~m}$ ); (b) celestine inclusion with barite in the centre (same sample as in a); (c) barite crystals in dolomicrite (sample TZ14-4; $65 \mathrm{~m}$ ).
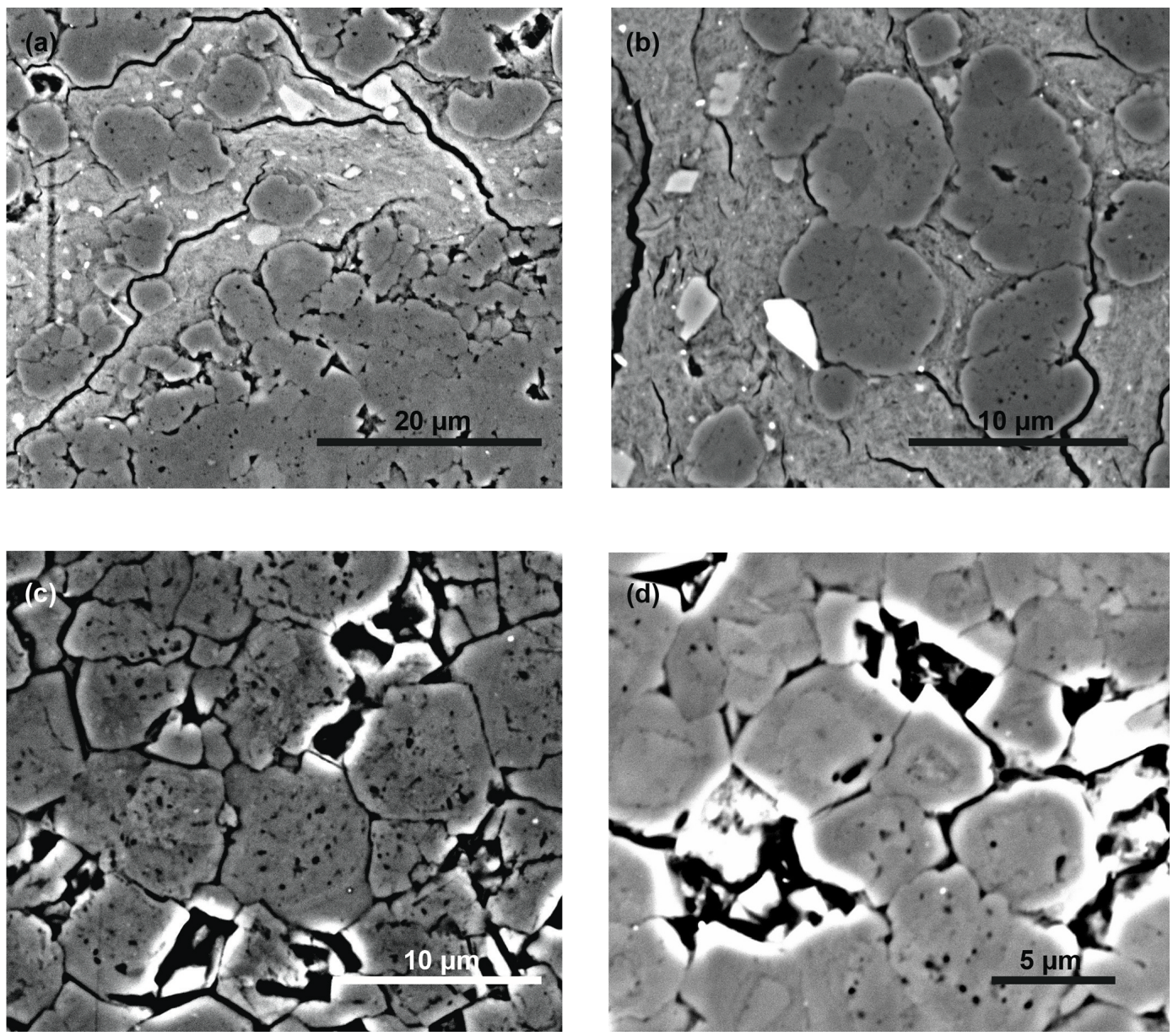

Figure 6. SEM images of dolomites in backscatter mode showing different types of crystal shape: (a) spheroidal growth of dolomite (darker areas) in clay layers (brighter areas; sample TZ14-9d; $95 \mathrm{~m}$ ); (b) close-up of (a); (c, d) dolomite crystals showing a porous interior and homogeneous syntaxial cement rims (c: sample TZ14-12; $90 \mathrm{~m}$; d: sample TZ14-9d; $95 \mathrm{~m}$ ). 


\subsubsection{Germanic Keuper dolomites}

A sample from the Weser Fm. (middle Lehrberg bed; clay pit Friedland, $12 \mathrm{~km}$ south of Göttingen, northern Germany; Seegis, 1997; Arp et al., 2004; Rieder et al., 2019) exhibits a brittle structure with high porosity. The material consists mainly of packed ooids with few peloids in a sparitic cement matrix. Under the SEM, subhedral to euhedral dolomites in the $5 \mu \mathrm{m}$ range are observed within the ooids (not shown).

A sample from the Norian Arnstadt Fm. (formerly termed "Steinmergelkeuper"; middle grey series; locality of Krähenberg, $11 \mathrm{~km}$ SSW of Göttingen, northern Germany; Arp et al., 2005) shows millimetre-scale lamination and centimetreto decimetre-sized laminated clasts, which were interpreted as a stromatolite breccia. The laminae contain abundant agglutinated siliciclastic grains (mainly quartz, subordinate albite) and phosphoritic fish scales. The dolomicrite exhibits a subhedral structure in the $\leq 5 \mu \mathrm{m}$ range with a few larger, subhedral grains resulting in a porphyrotopic fabric.

\subsection{Mineralogy}

Bulk dolomite shows a position of the 104 peak at a mean $d$ value of $2.88816 \AA$ (Fig. 7a). This indicates a Ca content of $50.7 \%$, based on the equation of Lumsden (1979). The structural order is indicated by the ratio of the superlatticeordering peak at 015 to the 110 ordering peak. The height ratio is 0.44 , which is near 0.519 (inset in Fig. 7a), indicated for an ordered dolomite in the Highscore database.

Clay mineral analysis (Fig. 7b-d) reveals illite in samples TZ14-1 and TZ14-7 and an R3 ordered illite-smectite mixedlayer clay mineral in sample TZ14-9. In the ethylene-glycolsaturated state, the broad shoulder at $11.4 \AA$ contains components of the illite 001 reflection and of the fourth order of a $47 \AA$ superstructure peak whose unit cell consists of three $10 \AA$ illite layers and one $17 \AA$ smectite layer (Moore and Reynolds, 1997). This smectite component is not observed in samples TZ14-1 and TZ14-7.

\subsection{Carbon and oxygen isotopes}

Carbon isotope values range from $-3.38 \%$ to $+4 \%$ Vienna Peedee Belemnite (VPDB). Oxygen isotope values are between $-0.7 \%$ and $+0.9 \%$ VPDB (three outliers show values as low as $-1.5 \%$ VPDB; Fig. 8a; Rieder et al., 2019). A clear distinction occurs between nodular dolomites exhibiting negative $\delta^{13} \mathrm{C}$ values and homogeneous dolomites showing positive values. Laminated dolomites exhibit intermediate values and low variability. The oxygen isotopes show an upward increasing trend (Fig. 8b). The calculated temperature of formation assuming a Triassic seawater composition of $-1 \%$ Vienna standard mean ocean water (VSMOW) using the fractionation equation of Vasconcelos et al. (2005) results in temperatures between 29 and $39^{\circ} \mathrm{C}$; more positive values would result in higher water temperatures.

\subsection{Elemental composition of the dolomites}

Sequentially extracted samples TZ14-1, TZ14-7, and TZ149 (Rieder et al., 2019) show Ca contents between 1.68 and $2.33 \mathrm{mmol} \mathrm{g}^{-1}$ in the $0.1 \mathrm{~N}$ acetic acid fraction and between 2.71 and $2.87 \mathrm{mmol} \mathrm{g}^{-1}$ in the $1 \mathrm{~N}$ acetic acid fraction. $\mathrm{Mg}$ contents are between 1.61 and $2.34 \mathrm{mmol} \mathrm{g}^{-1}$ in the $0.1 \mathrm{~N}$ acetic acid fraction and between 2.48 and $2.64 \mathrm{mmolg}^{-1}$ in the $1 \mathrm{~N}$ acetic acid fraction. Based on these concentrations, the amount of dolomite dissolved is between 30 and $43 \mathrm{wt} \%$ of the bulk sample in the $0.1 \mathrm{~N}$ acetic acid fraction and between $49 \mathrm{wt} \%$ and $52 \mathrm{wt} \%$ in the $1 \mathrm{~N}$ acetic acid fraction of the sequential extraction. In total, between $84 \mathrm{wt} \%$ and $90 \mathrm{wt} \%$ of the bulk sample were dissolved during these two extraction steps. If molar concentrations of $\mathrm{Ca}$ are plotted vs. $\mathrm{Mg}$, a linear trend with a slope of 0.935 is observed (Fig. 9a), indicating $48.3 \mathrm{~mol} \% \mathrm{MgCO}_{3}$ in the dolomite phase.

Correlation of $\mathrm{Sr}$ contents to other elements did not show clear trends. In particular, $\mathrm{Sr}$ content did not correlate with $\mathrm{Mg}$ or Ca. Sr correlates with K (Fig. 9b), but at the same time, $\mathrm{K}$ is extremely low in all clay mineral leachates. The $\mathrm{Sr}$ concentrations in bulk dolomite samples (Fig. 10a-c) are in the range of 0.38 and $1.16 \mu \mathrm{molg}^{-1}$ in the $0.1 \mathrm{~N}$ acetic acid fraction and between 0.57 and $0.79 \mu \mathrm{molg}^{-1}$ in the $1 \mathrm{~N}$ acetic acid fraction (except one extremely high value of $34.91 \mu \mathrm{mol} \mathrm{g}^{-1}$ in sample TZ14-9). These contents are much higher than in pure clay mineral samples (Fig. 10d) with $0.047-0.417 \mu \mathrm{molg}^{-1}$ in the $0.1 \mathrm{~N}$ acetic acid fraction and even lower concentrations $\left(<0.19 \mu \mathrm{mol} \mathrm{g}^{-1}\right)$ in the other fractions. In all samples measured by ICP-OES, rubidium $(\mathrm{Rb})$ concentrations are below the detection limit of $0.012 \mu \mathrm{mol} \mathrm{g}^{-1}$.

\section{5 $\mathrm{Sr}$ isotopes}

\subsection{1 ${ }^{87} \mathrm{Sr} /{ }^{86} \mathrm{Sr}$ evolution during leaching experiments}

Results of Sr-isotope measurements are available from Rieder et al. (2019). Results of sequential and non-sequential leaching tests of bulk samples TZ14-1, TZ14-7, and TZ14-9 are shown in Fig. 10a-c. ${ }^{87} \mathrm{Sr} /{ }^{86} \mathrm{Sr}$ ratios decrease in sample TZ14-1 from $0.708125 \pm 0.000012$ to $0.707666 \pm 0.000004$ with increasing strength of the leaching reagent, while the values remain almost constant in sample TZ14-9. The values of bulk dolomite extracted with $1 \mathrm{~N}$ acetic acid are slightly lower than in the fraction extracted with $0.1 \mathrm{~N}$ acetic acid; only microdrilled samples show higher values. However, repeating the $0.1 \mathrm{~N}$ acetic acid extraction (for $36 \mathrm{~h}$ ) after a rather intense first extraction $(4,12,4 \mathrm{~h})$ results in extremely high values $(0.715417 \pm 0.000250$ in TZ14- 1 and $0.7192266 \pm 0.000455$ in TZ14-9; not shown in Fig. 10). Standard deviations are also higher than in the other fractions. Highest ${ }^{87} \mathrm{Sr} /{ }^{86} \mathrm{Sr}$ ratios of up to $0.730453 \pm 0.000005$ in sample TZ14-7 are reached by extraction with $6 \mathrm{~N} \mathrm{HCl}$. At 
(a)

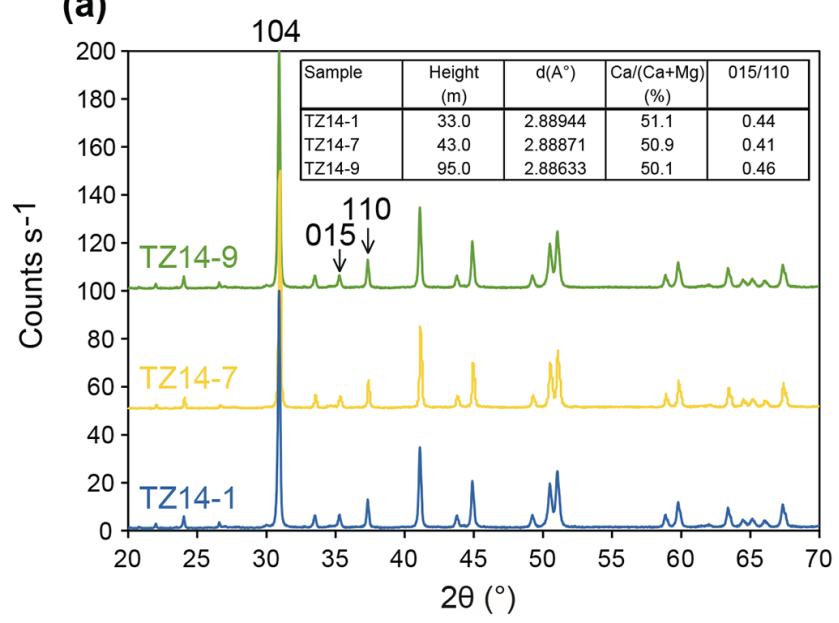

(c)

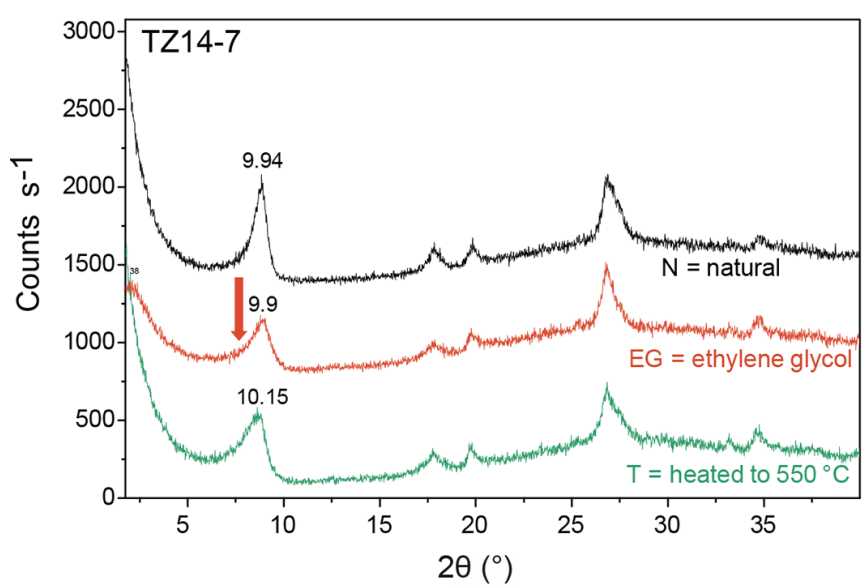

(b)

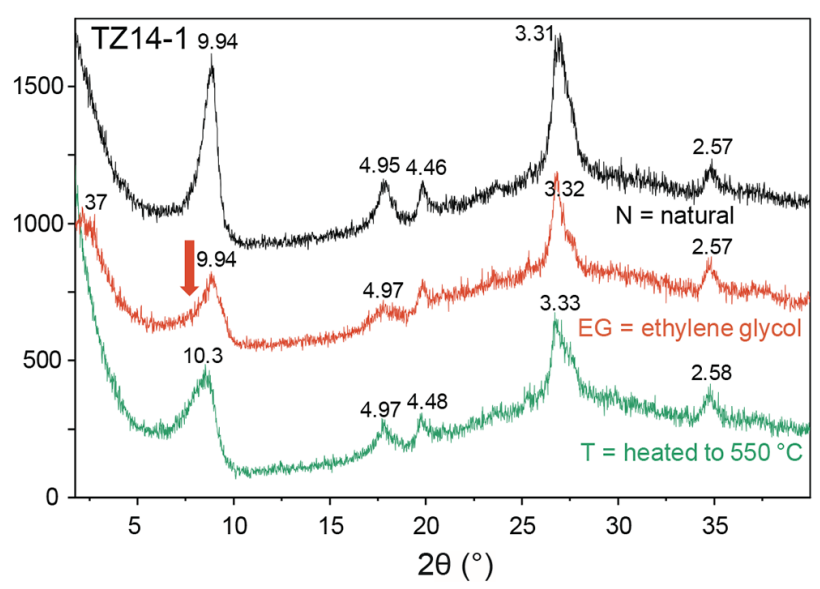

(d)

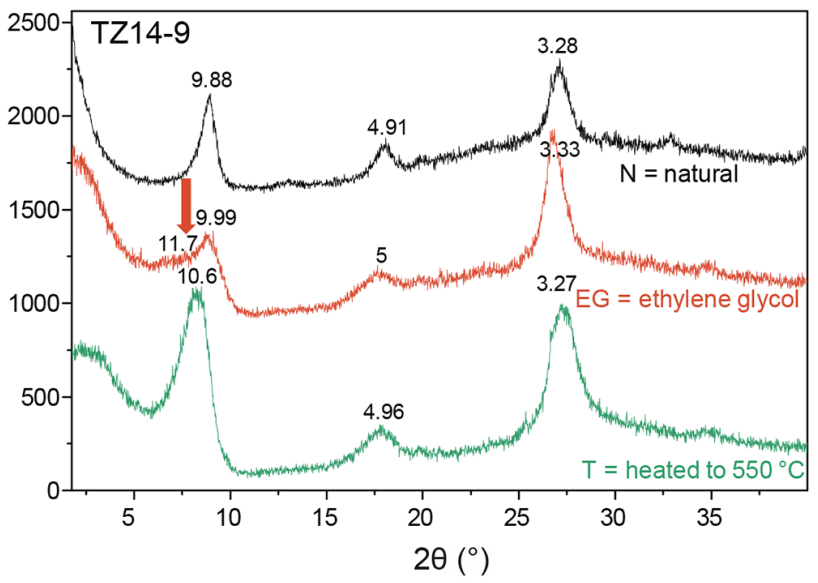

Figure 7. X-ray diffraction patterns: (a) bulk analyses of homogeneous dolomite (samples TZ14-1, TZ14-7, and TZ14-9); main peaks and ordering peaks are labelled with (hkl) indices. The inset in (a) shows the $\mathrm{Mg} /(\mathrm{Ca}+\mathrm{Mg}$ ) ratios in the dolomites determined from the shift of the 104 peak using the equation of Lumsden (1979) and the structural ordering calculated from the ratio of the 015 ordering peak to the 110 peak according to Füchtbauer and Goldschmidt (1966). (b-d) Clay mineral separates of samples TZ14-1, TZ14-7, and TZ14-9, air dried (N), saturated with ethylene glycol (EG), and heated to $550{ }^{\circ} \mathrm{C}(\mathrm{T}) ; d$ values in $\AA$. The illite-smectite mixed layer is best seen in the ethylene-glycol-saturated sample TZ14-9. The arrow points to the expandable (smectite) part of the mixed layer.

the same time, these fractions show the lowest $\mathrm{Sr}$ concentrations (see above).

Sequential extractions of the clay samples TZ16-1 and TZ16-19B with the lowest TIC of $0.02 \mathrm{wt} \%$ (Fig. 10d; Rieder et al., 2019) show a similar increase in the ${ }^{87} \mathrm{Sr} /{ }^{86} \mathrm{Sr}$ ratio with the sequential extraction steps from $0.1 \mathrm{~N}$ acetic acid to $6 \mathrm{~N} \mathrm{HCl}$, reaching similar values as in the $\mathrm{HCl}$ fraction of the dolomites $(0.722998 \pm 0.000018$ to $0.733910 \pm$ $0.000024)$.

Repeated extractions of chemically pure reference material (Fig. 10e, f) dissolved in $0.1 \mathrm{~N}$ acetic acid show a range of ${ }^{87} \mathrm{Sr} /{ }^{86} \mathrm{Sr}$ ratios in dolomite between $0.709942 \pm 0.000011$ and $0.710831 \pm 0.000007$. Pure single crystals of dolomite extracted sequentially show the highest value $(0.708401 \pm$ 0.000040 ) in the $1 \mathrm{M} \mathrm{NaCl}$ fraction. Values in the $0.1 \mathrm{~N}$ acetic acid fraction $(0.707735 \pm 0.000006)$ and the $1 \mathrm{~N}$ acetic acid fraction $(0.707666 \pm 0.000006)$ are lower by almost 0.001 compared to the $\mathrm{NaCl}$ fraction.

In pure barite, ${ }^{87} \mathrm{Sr} /{ }^{86} \mathrm{Sr}$ ratios decrease by about 0.0013 in the extraction sequence from $0.1 \mathrm{~N}$ acetic acid to $6 \mathrm{~N}$ $\mathrm{HCl}$. Celestine is highly soluble and was only measured in the $1 \mathrm{M} \mathrm{NaCl}$ fraction and once in $0.1 \mathrm{~N}$ acetic acid. Extracts of pure celestine show similar values as in the $1 \mathrm{M} \mathrm{NaCl}$ fraction of the barite-celestine-dolomite mixture $(0.708038 \pm 0.000003)$, but the mixture shows higher values $(0.709501 \pm 0.000040)$ in the $0.1 \mathrm{~N}$ acetic acid fraction.

\subsection{2 ${ }^{87} \mathrm{Sr} /{ }^{86} \mathrm{Sr}$ ratios in microdrilled dolomite}

Eleven dolomite samples were microdrilled from areas where dolomite was purest based on examination by SEM and dissolved in $0.1 \mathrm{~N}$ acetic acid. The values of the Trave- 
(a)

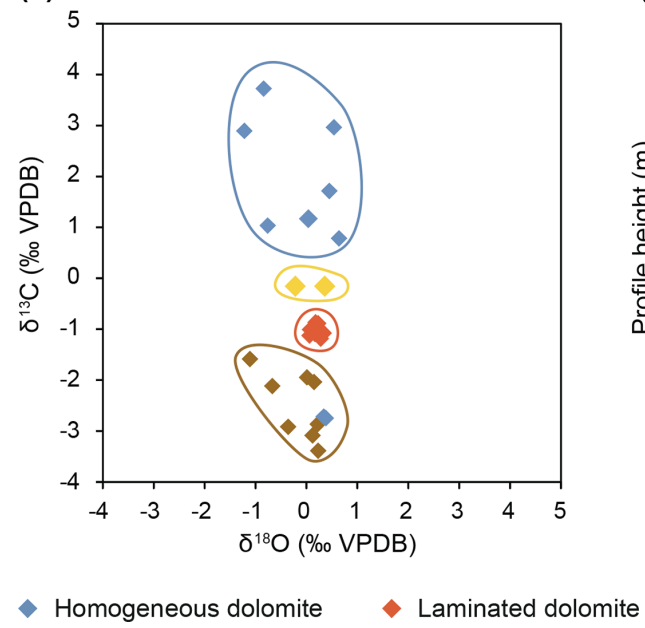

(b)

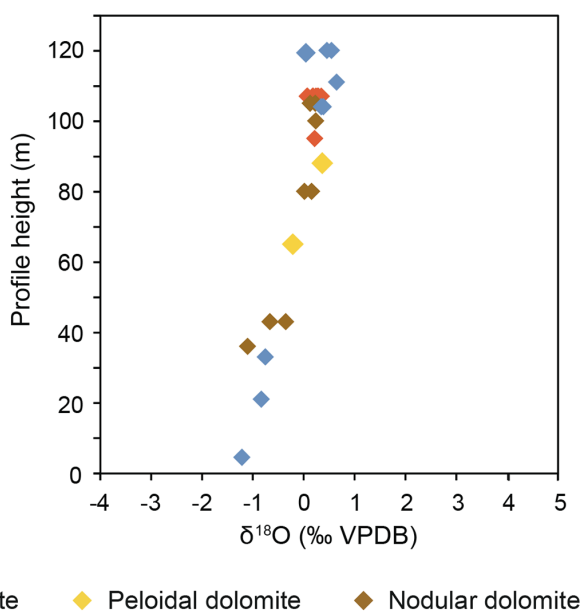

Figure 8. (a) Carbon-oxygen isotope cross plot shows a clear distinction between homogeneous, laminated, peloidal, and nodular dolomites. Nodular dolomites are probably influenced by carbon derived from organic matter. (b) Oxygen isotope values $\left(\delta^{18} \mathrm{O}\right)$ show a positive trend with a gradient of $2 \%$ over the $100 \mathrm{~m}$ thick stratigraphic section. This could be due to a decrease in precipitation temperature or to a change in the $\delta^{18} \mathrm{O}$ of the water over time.

(a)

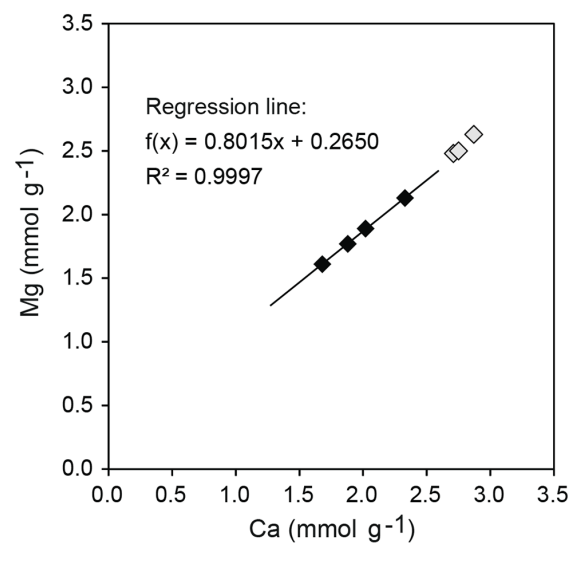

$0.1 \mathrm{~N}$ acetic acid (b)

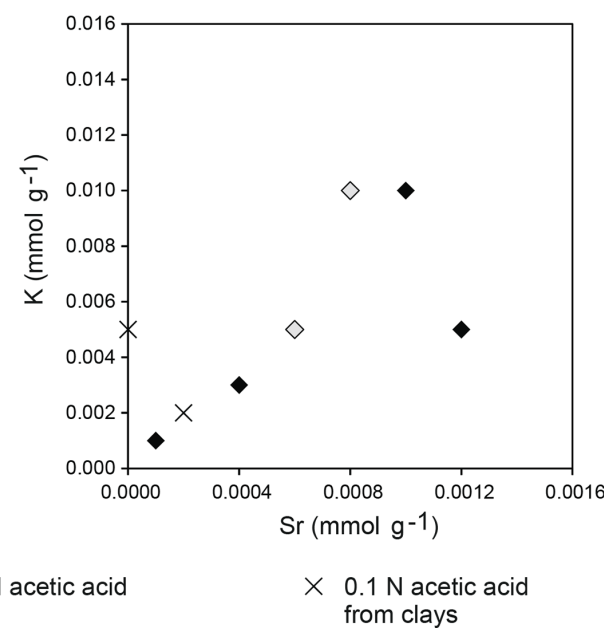

Figure 9. Element concentrations in sequentially extracted fractions of bulk dolomite and clay samples of the Travenanzes Fm.: (a) Ca plotted vs. Mg shows a linear trend, reflecting nearly the $1: 1$ stoichiometry of dolomite; (b) Sr shows some correlation with K, which could be due to incorporation in rapidly precipitating dolomite (see text for discussion).

nanzes Fm. are in the range of $0.707672 \pm 0.000003$ to $0.707976 \pm 0.000004$ (Fig. 11). The highest value occurs in a dolomite nodule, while no systematic difference between homogeneous and laminated dolomite was observed. Dolomite of the Germanic Keuper samples shows significantly higher ${ }^{87} \mathrm{Sr} /{ }^{86} \mathrm{Sr}$ ratios of $0.709303 \pm 0.000006$ and $0.709805 \pm 0.000005$, respectively.

\subsection{3 ${ }^{87} \mathrm{Sr} /{ }^{86} \mathrm{Sr}$ ratios of modern dolomites (Deep Springs Lake, Coorong lakes)}

Dolomites of Deep Springs Lake show strongly radiogenic values of $0.713086 \pm 0.000004$ and $0.713207 \pm 0.000004$ (Fig. 12), which are much higher than modern seawater values, with a ${ }^{87} \mathrm{Sr} /{ }^{86} \mathrm{Sr}$ ratio of $0.709234 \pm 0.000009$ (DePaolo and Ingram, 1985). In contrast, dolomite from the Coorong lakes (Milne Lake; Fig. 12) exhibits ratios between $0.709251 \pm 0.000004$ and $0.709275 \pm 0.000003$, which is very close to the ratio of modern seawater. Different incubation 
(a)

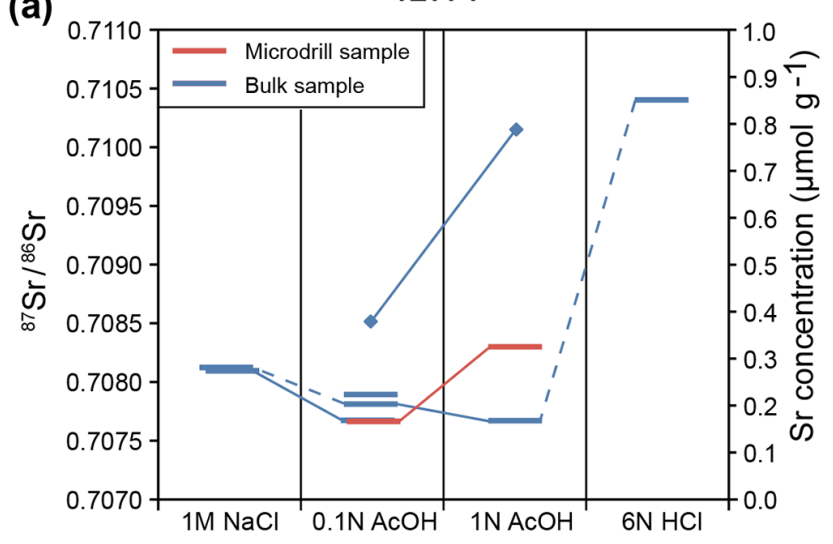

(c)

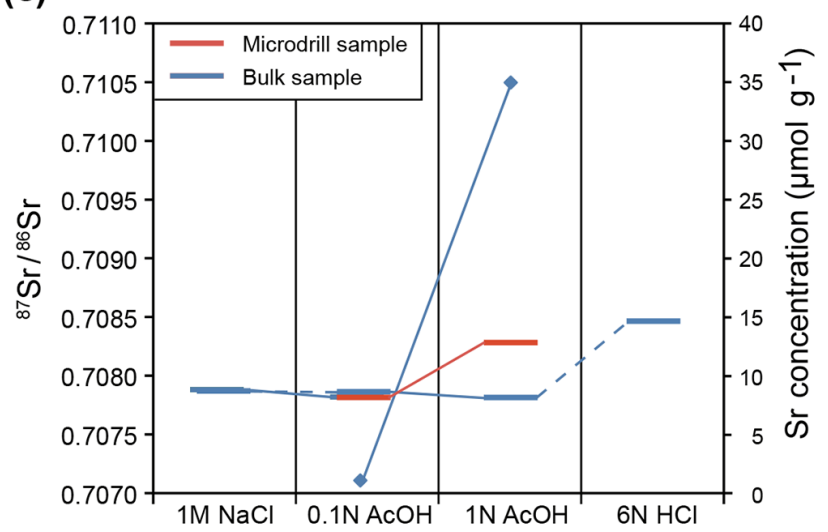

(e)

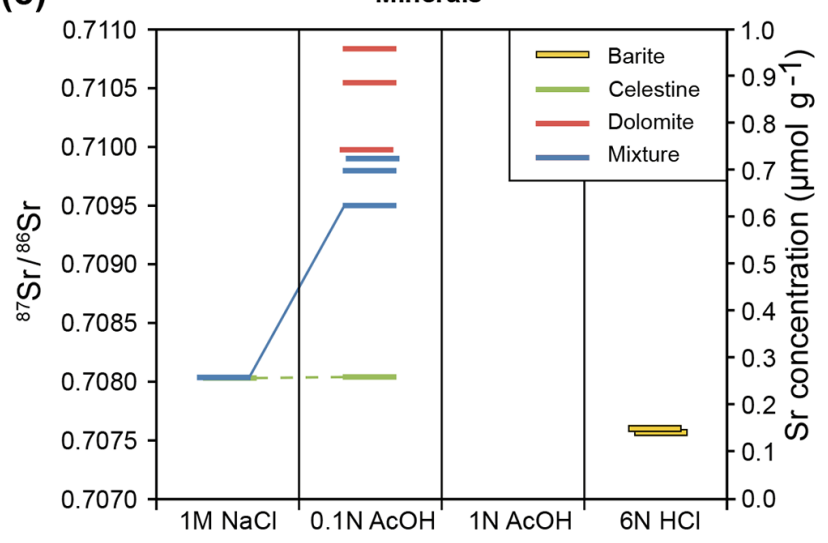

(b)

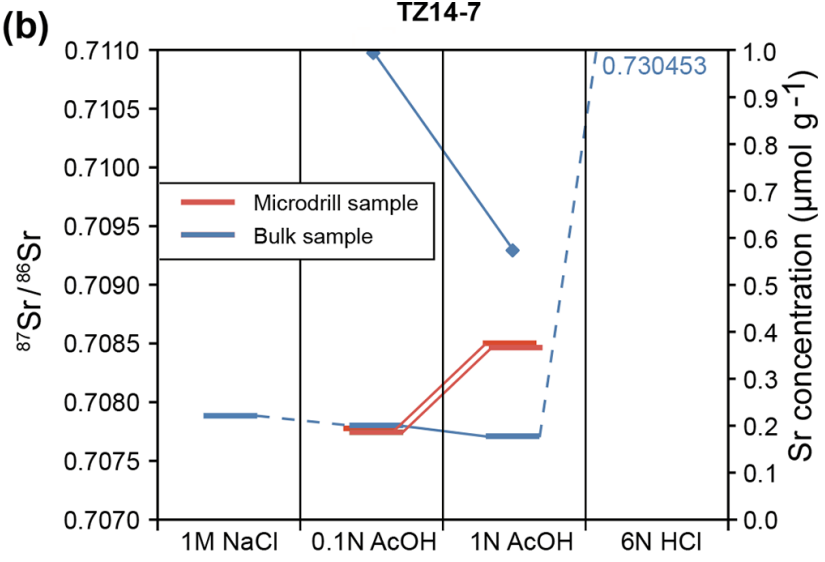

(d)

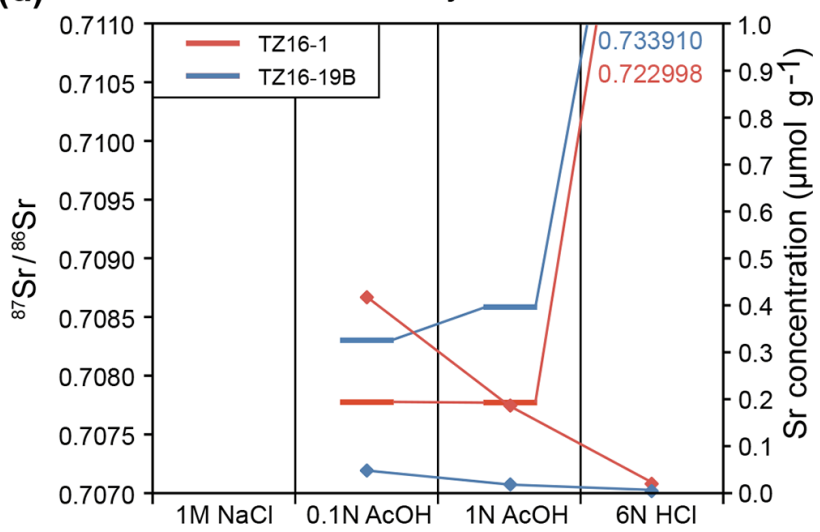

(f)

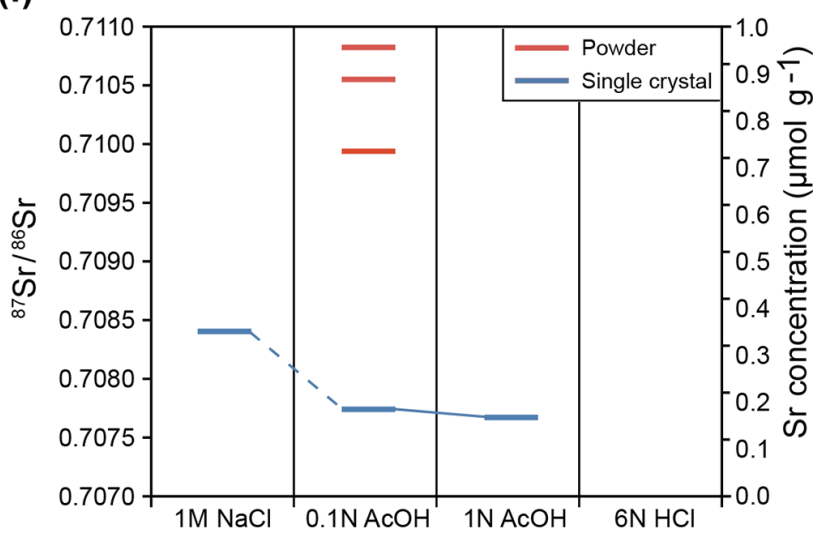

- Sr concentration

Figure 10. Sr-isotope ratios and $\mathrm{Sr}$ concentrations measured in sequential and non-sequential extractions of dolomite and different control minerals. (a-c) Dolomite samples of the Travenanzes Fm. show consistently low Sr-isotope values (below 0.708000 ) in the $0.1 \mathrm{~N}$ acetic acid fraction and very high values in the $\mathrm{HCl}$ fraction. The values in the $1 \mathrm{~N}$ acetic acid fraction are higher in the microdrilled samples, perhaps due to partial leaching of residual clay minerals. In bulk samples values are low, while concentrations indicate still abundant $\mathrm{Sr}$, presumably from the dolomite phase. (d) Claystone samples show generally elevated Sr-isotope values (compared to the dolomite samples) and lower concentrations. Low Sr-isotope values and higher concentrations in the acetic acid fractions of sample TZ16-19B could be due to traces of carbonate in the sample. (e, f) Pure control materials, including barite, celestine, dolomite, and a mixture of these minerals show clear separation of the three fractions. Sr-isotope values in dolomites show some scattering, probably due to inhomogeneities in the powder and the single crystals. The $2 \sigma$ uncertainties are smaller than the symbol size. 


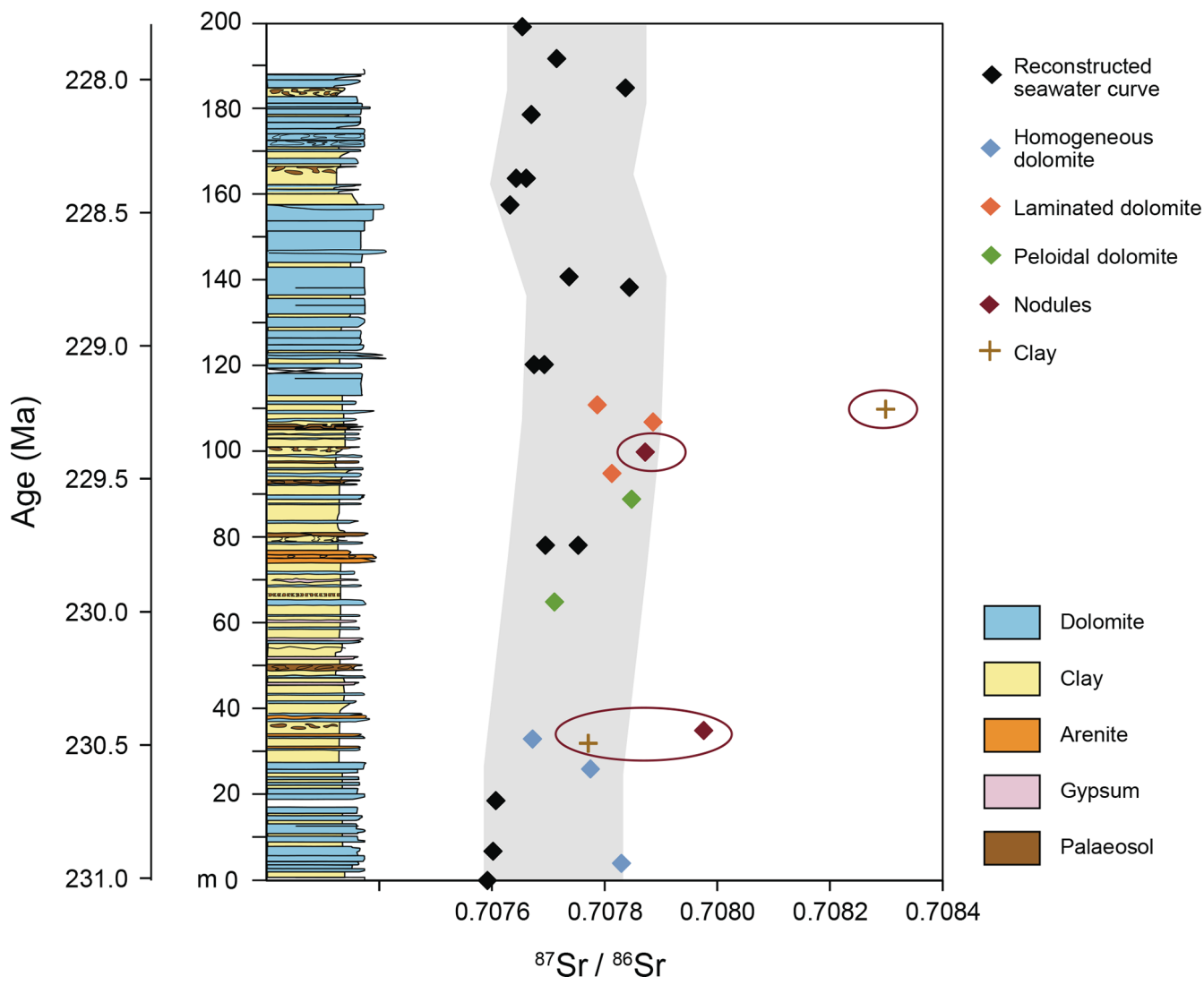

Figure 11. Comparison of Sr isotopes in dolomites of the Travenanzes Fm. with the Carnian seawater curve (Korte et al., 2003) in grey. The $2 \sigma$ uncertainties are smaller than the symbol size. Circled data points are clay samples or samples of nodules containing clay.

times $(5 \mathrm{~min}$ and $10 \mathrm{~h})$ in $0.1 \mathrm{~N}$ acetic acid had no influence on the isotope ratios.

\section{Discussion}

\subsection{Interpretation of microfacies within different types of dolomite}

\subsubsection{Homogeneous dolomite beds}

The homogeneous dolomite beds, which are mainly intercalated in the lower, clay-rich part of the Travenanzes Fm., consist of fine-grained dolomicrite (aphanotopic dolomite), with occasional intraclasts of the same aphanotopic dolomite. Soft sediment deformation and dolomicrite infill between mud clasts indicate that this sediment consisted of unlithified, albeit cohesive, carbonate mud. Based on the abundance of fine mud, water energy was probably not very high (Demicco and Hardie, 1994), although reworking and partial rounding of the mud clasts requires at least occasionally higher water energies. According to the standard microfacies (SMF) concept, homogeneous aphanotopic dolomite falls into SMF 23 ("non-laminated homogeneous micrite and microsparite without fossils"), indicating deposition in "saline and evaporative environments, e.g. in tidal ponds" (Flügel, 2010). In addition, SMF 24 ("lithoclastic floatstones, rudstones and breccias") is observed in some of the beds where mud clasts are abundant. These facies types are consistent with supersaturation-driven precipitation of fine-grained authigenic carbonate in environments that were partially disconnected from open seawater and would match with a coastal sabkha environment and/or shallow ephemeral lake. Ephemeral lakes may have formed on extended coastal alluvial plains along the Tethyan margin during the Carnian, as suggested by Breda and Preto (2011). The fine mud may have been homogenized and redistributed due to minor wave action in the ponds (see Ginsburg, 1971), which is often observed in ephemeral lake settings, explaining the formation of homogeneous dolomite beds.

Episodic flooding of the alluvial plain by the dryland-river system may have supplied water to temporary evaporating ponds. Alternatively, the alluvial plain may have been sporadically flooded by seawater, explaining the intercalations of authigenic dolomite layers with alluvial clays (Breda and Preto, 2011). Homogeneous dolomites show a positive carbon isotope signature between $0.7 \%$ and $4 \%$ VPDB (except one outlier), which is consistent with formation from unaltered marine carbon in evaporative brine, with no signif- 


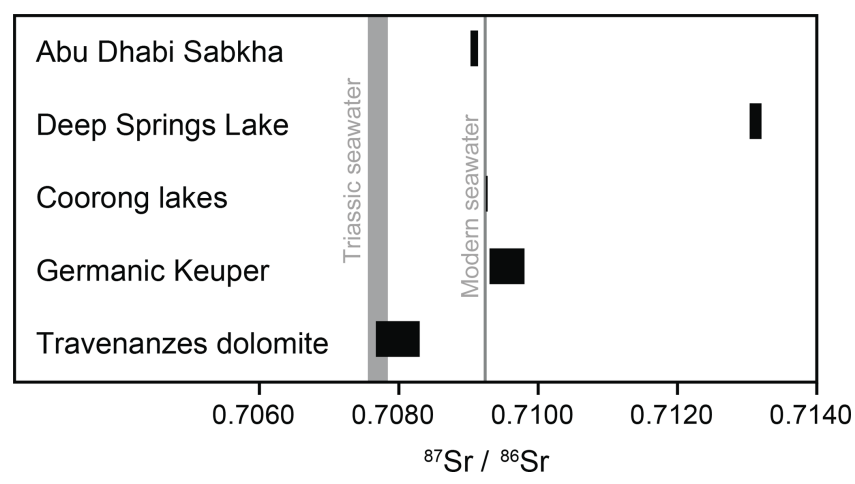

Figure 12. Sr-isotope values $\left({ }^{87} \mathrm{Sr} /{ }^{86} \mathrm{Sr}\right.$ ratios) in dolomites from different modern environments (Abu Dhabi Sabkha, Deep Springs Lake, Coorong lakes) and from ancient environments (Germanic Keuper - Weser Fm. and Arnstadt Fm.; Travenanzes Fm. of the Dolomites, southern Alps) in comparison with modern seawater (DePaolo and Ingram, 1985) and Triassic seawater (Korte et al., 2003).

icant contribution of ${ }^{12} \mathrm{C}$ derived from organic matter. Evaporative conditions are also indicated by several gypsum beds that occur between 45 and $70 \mathrm{~m}$ in the section and pseudomorphs after gypsum, which are observed in a thin section of a dolomite at $120 \mathrm{~m}$ (Fig. 4c, d). However, evaporites may not always be preserved, as they are frequently dissolved due to seasonally wet conditions.

A bed of dolomitic ooid grainstone that is devoid of matrix occurs at $64 \mathrm{~m}$ (Fig. 4e), and tempestites with moldic porosity indicative of dissolved allochems and dissolved fossils occur at several levels in the section, always associated with homogeneous dolomites. These beds must represent events of higher water energy, contributing sediment from more open marine areas. The presence of marine fossils, such as Megalodon bivalves, indicates that the environment was influenced by marine conditions, at least episodically. The microfacies of the oolite falls into SMF 15, which indicates proximity to the seaward edge of the platform. Several beds containing abundant siliciclastic material (mainly angular quartz clasts) are likely due to a riverine flooding event, which provided detrital material from the continent. In general, the microfacies in the homogeneous dolomite beds reflects both marine and continental influences on the depositional environment.

\subsubsection{Laminated dolomite}

Laminated dolomites reminiscent of loferites (Fischer, 1964) occur in the upper part of the clay-rich interval. The change from more homogeneous to laminated dolomite intercalations correlates with the change from red to dark grey clay. The laminations consist of millimetre-scale dolomite-clay interlayers, suggesting alternating deposition of clay and fine dolomite. This microfacies falls into SMF 25 ("laminated evaporite-carbonate mudstone facies"), indicating an "upper intertidal to supratidal sabkha facies in arid and semi- arid coastal plains and evaporitic lacustrine basins" (Flügel, 2010). Laminae showing soft sediment deformation cannot be attributed to stromatolitic bindstone facies (SMF 19 to 21). Only some layers that show a coarser fabric with interstitial dolosparite or dolomicrosparite containing putative peloids have been interpreted as microbial laminites (Preto et al., 2015). Graded bedding mostly indicates a direct sedimentation process rather than in situ precipitation of the primary carbonate within a microbial mat (Vasconcelos et al., 2006; Bouton et al., 2016; Court et al., 2017; Perri et al., 2018). A detrital origin of the clay in the dolomites is confirmed by a well-ordered illite-smectite mixed-layer composition, which is atypical for authigenic clay minerals. Frequent subaerial exposure and desiccation may explain why the sediment was not homogenized and the lamination is preserved. This is supported by the occurrence of pseudo-teepee structures as remnants of desiccation cracks. Rip-up clasts were formed during subsequent flooding, when angular flat pebbles formed as the sediment was desiccated or partially lithified. However, laminae commonly exhibit plastic deformation (e.g. in Fig. 3g) where the mud was still unlithified.

Some uncertainty exists as to whether this facies was peritidal or represents an ephemeral lake, as suggested for the homogeneous dolomites above. Episodic high water energy, as indicated by the rip-up clasts, combined with frequent desiccation, could point to evaporative tidal conditions that occur in a sabkha. What is atypical for a modern sabkha is the large amount of clay input. This is attributed to seasonally wet conditions during the Carnian, and the sediments can be considered to be a mixed facies of alluvial plain and coastal sabkha: a "dirty" sabkha (see discussion below). Under such conditions, large amounts of evaporites, in particular gypsum, could have been dissolved. Why the occurrence of laminated dolomites coincides with the transition from red to grey clays is not clear, but it may be related to more permanently water-saturated conditions in the subsurface, while the surface was exposed to periodic desiccation. These conditions would also be consistent with a sabkha environment.

\subsubsection{Nodular dolomite}

During intervals of arid conditions, the clay beds were subject to strong evaporation and vadose diagenesis, causing oxidation and the red colour. Although red beds may also form in humid environments if drainage is rapid (Sheldon, 2005), drainage was certainly slow due to the large amounts of poorly permeable clay in the Travenanzes Fm., and the climate was clearly seasonally arid (Breda and Preto, 2011). Dolomite nodules that occur sporadically within certain intervals show internal brecciation, which must have occurred after sedimentation. Internal brecciation is a typical feature of present-day calcretes in arid environments (e.g. Mather et al., 2018). Slightly negative $\delta^{13} \mathrm{C}$ values indicate a contribution of carbon derived from organic matter degradation, further suggesting that they formed within the sediment. The 
formation of dolomite nodules could presumably be related to diagenesis in palaeosols. In the upper part of the section (between 80 and $105 \mathrm{~m}$ ) dolomite nodules are associated with green reaction haloes along vertical peds in palaeosols of Vertisol-Calcisol type (Preto et al., 2015). Carbonate formation may have been related to reducing fluids in water-logged soils during humid intervals, while the cracks formed during desiccation in dry periods, perhaps facilitated by the presence of expandable clay minerals (smectite).

\subsection{The origin of ionic solutions conducive to dolomite formation}

Overall, the dolomites in the Travenanzes Fm. show a facies association that matches a variety of potential depositional environments. They have similarities to the Germanic Keuper succession, and it is not entirely clear if a marine influence occurred, except where indicated by marine fossils, as in the tempestite beds. Sr isotopes were analysed in order to better trace the origins of ionic solutions to the environments that were conducive to dolomite formation.

\subsubsection{Strontium derived from seawater}

Radiogenic ${ }^{87} \mathrm{Sr} /{ }^{86} \mathrm{Sr}$ ratios can be indicative of the source of ionic solutions that the dolomite precipitated from (Müller et al., 1990a, b). Sr isotopes in selected dolomites from the Travenanzes Fm. at the Dibona section show values between $0.707672 \pm 0.000003$ and $0.707976 \pm 0.000004$. Ammonoids found at the base of the succession suggest a Tuvalian II age (subbullatus zone, 232.5-231.0 Ma; Ogg, 2012). The upper boundary of the Travenanzes Fm. is time-transgressive, and hence the exact age is not known. We assume that the sedimentation rate was at least as high, or higher, than in the peritidal carbonates of the Dolomia Principale. In this region, the Dolomia Principale includes a part of the Rhaetian (Neri et al., 2007) and, thus, its upper boundary is near the TriassicJurassic boundary at 201.3 Ma. Although the age interval of the Travenanzes Fm. is not precisely constrained, we correlate the Dibona section (Fig. 11) with the Carnian seawater Sr-isotope curve (Korte et al., 2003). The seawater curve was fixed at the lower boundary of the Travenanzes Fm. and the time axis was varied to fit the seawater curve parallel to the envelope of minimal ${ }^{87} \mathrm{Sr} /{ }^{86} \mathrm{Sr}$ ratios measured in the dolomites (Fig. 11). The base of the first massive dolomite at $110 \mathrm{~m}$ in the profile would therefore have an age of approximately 229 Myr.

Comparison with the seawater curve shows that the dolomites of the Travenanzes Fm. have largely marine ${ }^{87} \mathrm{Sr} /{ }^{86} \mathrm{Sr}$ ratios (Fig. 11). Only values from microdrilled samples extracted with $0.1 \mathrm{~N}$ acetic acid were used for this reconstruction, and the resulting values all lie within 0.00022 of seawater values (grey shaded area). This scatter towards more positive values, compared to seawater, may be due to a small influence by continental water. Indeed, during de- position of the Travenanzes Fm. sufficient continental water would have been available from rivers, and ions may have become concentrated while the water was evaporating in the distal alluvial plain. Alternatively, $\mathrm{Sr}$ desorbed from clay minerals could have added more radiogenic values to the brine. But even if a small influence of $\mathrm{Sr}$ of continental origin is present, the marine signal is dominant because of the much higher Sr concentrations in seawater.

The marine signature shown by the $\mathrm{Sr}$ isotopes does not support the classical Coorong model for dolomite formation, where alkalinity is largely derived from continental groundwater. The Coorong lakes in South Australia are ephemeral lakes largely supplied by groundwater (Von der Borch et al., 1975). Strangely, though, the ${ }^{87} \mathrm{Sr} /{ }^{86} \mathrm{Sr}$ ratios we measured from Milne Lake (one of the Coorong lakes) are similar to the ratio in modern seawater (Fig. 11), but this can be explained, as the local groundwater largely originates from a Pleistocene carbonate aquifer and, accordingly, carries a Pleistocene Sr-isotope signature. A similar scenario for the Travenanzes Fm. is unlikely as the only large-scale preceding carbonate platforms at that time were the upper LadinianCarnian Cassian dolomite platforms (Russo et al., 1997). Based on the stratigraphic context, all basins between these platforms were infilled by the Heiligkreuz Fm. and an extremely flat topography was later established that is stratigraphically overlain and sealed by the alluvial deposits of the laterally persistent Travenanzes Formation. Furthermore, the Travenanzes Fm. consists of 100 m of impermeable clay (including expandable clays), such that the long-distance transport of groundwater can be excluded.

We conclude that the ${ }^{87} \mathrm{Sr} /{ }^{86} \mathrm{Sr}$ ratios of the dolomites represent a predominantly marine influence. Presumably, seawater was transported to the interior of a coastal plain by episodic flooding (spring tide or storm) events. Even in a seasonally wet climate, the contribution of $\mathrm{Sr}$ from river water was insignificant compared to the influence of ions (including Sr) from seawater that was concentrated by evaporation. Laminated dolomites in the uppermost part of the section show values most similar to seawater composition, which is consistent with a greater influence of peritidal conditions.

\subsubsection{The influence of $\mathrm{Sr}$ adsorbed to clay minerals}

Despite precautions to prevent contamination by other mineral phases by microdrilling and using mild reagents, some scatter occurs in the Sr-isotope data. Higher ${ }^{87} \mathrm{Sr} /{ }^{86} \mathrm{Sr}$ ratios in a dolomite nodule may be due to a continental influence or perhaps more seasonally wet and evaporative conditions with less of a marine influence. But higher values also may be due to contamination and partial leaching of clay minerals within the dolomite samples. Within the extraction sequence (1 M $\mathrm{NaCl} \rightarrow 0.1 \mathrm{~N}$ acetic acid $\rightarrow 1 \mathrm{~N}$ acetic acid), the ${ }^{87} \mathrm{Sr} /{ }^{86} \mathrm{Sr}$ ratio generally remains constant or becomes slightly less radiogenic, i.e. more similar to seawater. However, the values strongly increase with leaching in $6 \mathrm{~N} \mathrm{HCl}$ (Fig. 10). A mod- 
ification of ${ }^{87} \mathrm{Sr} /{ }^{86} \mathrm{Sr}$ ratios due to contamination by ${ }^{87} \mathrm{Sr}$ from the radioactive decay of ${ }^{87} \mathrm{Rb}$ to ${ }^{87} \mathrm{Sr}$ can be regarded as negligible since the concentrations of $\mathrm{Rb}$ was below the detection limit of $0.05 \mathrm{ppm}$ (Rieder et al., 2019), and the half life is 48.8 billion years (Neumann and Huster, 1974). In addition, the influence of celestine and Sr-rich barite, which were observed under SEM, on Sr-isotope values can also be largely excluded. These mineral phases are bound to distinct layers of the laminated dolomites, and they could be avoided by microdrilling areas where the dolomite is pure. Only one value from sample TZ14-9 shows extremely high $\mathrm{Sr}$ concentrations. This sample was microdrilled near a celestine layer, and it is therefore not surprising that a celestine crystal may have inadvertently been sampled. The isotopic composition of the celestine is also similar to Carnian seawater.

In the $\mathrm{NaCl}$ fraction, only minimal amounts of dolomite are dissolved. The slightly more radiogenic ${ }^{87} \mathrm{Sr} /{ }^{86} \mathrm{Sr}$ ratio may be derived from $\mathrm{Sr}$ that is lightly adsorbed to clay minerals and finely dispersed in the clay matrix, although $\mathrm{Sr}^{2+}$ as a two-valent cation is more strongly adsorbed to clay minerals than $\mathrm{Na}^{+}$and thus is not easily desorbed by $\mathrm{NaCl}$. The values approach seawater values in the $1 \mathrm{~N}$ acetic acid fraction with increasing extraction efficiency and purity of the carbonate phase. Values from microdrilled samples are also generally more similar to seawater values, probably because more pure dolomite was sampled (Rieder et al., 2019). Usually, $1 \mathrm{~N}$ acetic acid is observed to not strongly attack interlayer ions in clay minerals.

Clay minerals leached in $6 \mathrm{~N} \mathrm{HCl}$ show significantly more radiogenic values compared to dolomite samples. This finding is consistent with strongly radiogenic values in the $6 \mathrm{~N} \mathrm{HCl}$ fraction of dolomite samples (up to $0.730453 \pm$ 0.000005) and suggests that the clay minerals are the carriers of an Sr pool significantly more radiogenic than the carbonate phase showing marine values. $\mathrm{Sr}$ is known to adsorb to illite-smectite mixed-layer clay minerals (Missana et al., 2008). The $\mathrm{HCl}$ fraction most likely includes adsorbed $\mathrm{Sr}$ and $\mathrm{Sr}$ occupying the interlayer positions of the clay minerals and presumably also structurally bound $\mathrm{Sr}$ in the clay mineral phase. In particular, illite-smectite mixed-layer clay minerals, as detected by XRD of the clay mineral separate in sample TZ14-9 (Fig. 7d), could have two different origins: burial diagenesis and continental weathering. Based on the tectonic setting and shallow burial depth of the Dolomites, the burial depth for a smectite-illite transition has not been reached. Therefore, these minerals are most likely derived from silicate weathering, with the $\mathrm{Sr}$ signature representing the crustal origin of the parent rock. Our finding of radiogenic Sr-isotope ratios supports the interpretation that clay minerals did not incorporate $\mathrm{Sr}$ from seawater during a sealevel highstand. It is therefore clear that Sr extracted from the dolomites is not derived from clay minerals.

\subsubsection{Dolomite as primary archive of Sr-isotope signatures}

The question is whether the Sr-isotope ratio reflects the conditions of dolomite formation or whether it is inherited from a precursor phase. Baker and Burns (1985) and Vahrenkamp and Swart (1990) documented very small distribution coefficients between aqueous and solid solutions, and high $\mathrm{Sr}$ contents measured in Abu Dhabi Sabkha dolomites (Müller et al., 1990a) may be derived from precursor aragonite. However, if dolomite in the Travenanzes Fm. is largely primary (Preto et al., 2015) and, thus, not formed from an aragonite precursor, the $\mathrm{Sr}$ content should derive from the dolomite phase. Although some Sr may have been released due to replacement of the dolomite and excess $\mathrm{Sr}$ can explain the occurrence of celestine and barite inclusions, nanocrystal structures imply that primary dolomite is partially preserved. Indeed, Sánchez-Román et al. (2011) demonstrate a protodolomite forming in culture experiments that contains $\mathrm{Sr}$ in the range of several thousand parts per million. The incorporation mechanism of $\mathrm{Sr}$ is still not entirely clear, since $\mathrm{Sr}$ is a large ion that should occupy the sites of $\mathrm{Ca}$ in the crystal lattice. However, in Sánchez-Román et al. (2011), Sr appears to correlate with the $\mathrm{Mg}$ content, and another incorporation mechanism may occur, such as surface entrapment. Also the correlation of $\mathrm{Sr}$ contents with $\mathrm{K}$ contents could be explained by such a mechanism of $\mathrm{Sr}$ incorporation. Even if only protodolomite formed in microbial culture experiments (Gregg et al., 2015), natural modern dolomites are often rich in Sr (e.g. Meister et al., 2007). The Sr could occur in disordered nano-structural domains that are not picked up in the bulk XRD signal. Non-classical nucleation and growth pathways, e.g. by nanoparticle attachment, could play a role in the abnormal partitioning of $\mathrm{Sr}$ in the dolomite lattice. Thus, a high $\mathrm{Sr}$ content in the Travenanzes Fm. or in Abu Dhabi Sabkha dolomites is likely a true signature of primary dolomites.

\subsection{Mode of dolomite formation and comparison with known models}

\subsubsection{Primary dolomite formation}

Several results support a largely primary origin of dolomite in the Travenanzes Formation. Formation temperatures reconstructed from oxygen isotopes (assuming Triassic seawater composition of $-1 \%$ VSMOW) are between 28 and $33{ }^{\circ} \mathrm{C}$. If a typical ${ }^{18} \mathrm{O}$ enrichment of $3 \%$ o due to evaporation in a sabkha is assumed (McKenzie et al., 1980; McKenzie, 1981), the calculated temperatures are between 40 and $50{ }^{\circ} \mathrm{C}$, which is still within the possible range in a sabkha (see Hsü and Schneider, 1973). Both temperature and evaporation may have changed over time, which may explain the observed linear trend in oxygen isotopes across the section (Fig. 8b), although there is no covariation between $\delta^{13} \mathrm{C}$ and 
$\delta^{18} \mathrm{O}$ as it would be expected due to evaporation in hydrologically closed settings, such as the Germanic Keuper Basin (Reinhardt and Ricken, 2000; Arp et al., 2005). But also, the observed trend in $\delta^{18} \mathrm{O}$ would be too steep to be explained by overprinting within a normal geothermal gradient, and no signs of any hydrothermal activity occur in this region. In any case, the oxygen isotope data do not imply any post-depositional overprint, while nanocrystalline structures observed by Preto et al. (2015) preclude a later pervasive recrystallization during burial diagenesis. Sedimentary structures indicate that most of the homogeneous dolomite and laminae containing aphanotopic dolomite was unlithified, and dolomite was therefore deposited as fine-grained mud. This is further supported by millimetre-scale interlayering of clay and dolomite in the laminated dolomites near the top of the sequence, and some dolomite-clay couplets exhibiting fining-upward bedding. Based on the observation of nanocrystal structures, replacement did not take place, and it appears logical to assume that the primary phase was already dolomite.

While most of the dolomite may have been primary, micron-scale interstices between the dolomicrite grains must have been cemented after deposition. This cementation resulted in rims visible under SEM and results in nearhexagonal compromise boundaries. The cement may have contributed ${ }^{13} \mathrm{C}$-depleted carbon during early diagenesis. The lowest $\delta^{13} \mathrm{C}$ values of $-3.4 \%$ VPDB occur in the nodules. These nodules formed within the sediment, probably due to reducing conditions and influenced by dissolved inorganic carbon from degrading organic matter in the palaeosols. Homogeneous and laminated dolomites are clearly distinct from nodules in their carbon isotope compositions (Fig. 8a), indicating only a minor contribution from pore-water-derived dissolved inorganic carbon. Carbon isotope values are thus largely consistent with a primary precipitation. The mode of dolomite formation as fine mud and subsequent cementation is comparable to several modern sites of dolomite formation.

While dolomite formation under Earth surface temperatures has been suggested to be catalysed by microbes, perhaps via a secreted extracellular polymeric substance (EPS; see Bontognali et al., 2013), this mechanism is currently under debate (see Gregg et al., 2015). The present study neither supports nor rules out such a mechanism. We can raise the question whether microbial EPS is enriched in the surface waters, where it may affect precipitation of fine dolomite mud.

\subsubsection{The sabkha model}

The classical sabkha model involves dolomite formation under intertidal to supratidal conditions, the concentration of brines through either seepage reflux (Adams and Rhodes, 1960) or evaporative pumping (Hsü and Siegenthaler, 1969; Hsü and Schneider, 1973; McKenzie et al., 1980; McKenzie, 1981), and precipitation of dolomite as $\mathrm{Mg} / \mathrm{Ca}$ ratios in- creases due to gypsum precipitation (see Machel, 2004, for a more detailed discussion of varieties of sabkha models). This sabkha model allows for a mixture of seawater and continental groundwater, with seawater mainly providing the ions for dolomite precipitation. Coastal sabkhas are typically characterized by laminated (Lofer-type) dolomites, where the laminae are largely unlithified after deposition (Illing, 1965; Bontognali et al., 2010; Court et al., 2017). In the sabkha of Abu Dhabi, both pathways, via replacement of precursor aragonite and by direct precipitation of dislocation-ridden primary dolomite, are observed (Wenk et al., 1993).

The sabkha model is thus a reasonable model for the uppermost parts of the Travenanzes section, which contain laminated dolomites, marine Sr-isotope values, and indications of frequent desiccation and flooding in a peritidal setting. Yet, the conditions differed from the modern sabkhas along the Persian Gulf due to the large amount of alluvial clay (dirty sabkha), as opposed to aeolian sand. Most of the fine laminations may therefore result from periodically varying conditions, perhaps with clay deposition during episodes of fluvial discharge and carbonate deposition during evaporative conditions.

\subsubsection{The continental playa lake model}

The playa lake model was originally suggested by Eugster and Surdam (1973) for dolomite of the Green River Formation (Wyoming), but the primary formation of fine dolomite mud is observed in many alkaline playa lakes, such as Deep Springs Lake (Peterson et al., 1963; Clayton et al., 1968; Meister et al., 2011), Lake Acıgöl (Turkey; Balci et al., 2016), Neusiedler See (Austria; see Neuhuber et al., 2015), and Lake Van (Turkey; McCormack et al., 2018). For an overview see Eugster and Hardie (1978) and Last (1990). This type of setting has also been suggested for the Germanic Keuper deposits during the late Carnian and Norian, when the Germanic Basin was entirely disconnected from Panthalassa and was continental (Reinhardt and Ricken, 2000). The Travenanzes Fm., with its homogeneous dolomite intercalations in red and green clays, is strikingly similar to playa lake Keuper facies in the Germanic Basin. There, dolomite formed following evaporation and concentration of the continental brines under a semiarid climate.

Sr-isotope data, however, support a dominantly marine origin of ionic solutions to the Travenanzes Fm., whereas $\mathrm{Sr}$ isotopes are strongly radiogenic in the Germanic Keuper dolomites (or in Deep Springs Lake; Fig. 12). The two settings are thus fundamentally different. Even dolomite nodules, showing somewhat more radiogenic values than seawater in the Travenanzes Fm., still indicate a predominantly marine influence. The slightly more radiogenic influence could be due to clay minerals present in the nodules that were difficult to entirely separate from the carbonate. Also, dolomite nodules may have formed in relation to palaeosols, dur- 
ing somewhat more humid times and, thus, may have been slightly influenced by continental water input from rivers.

\subsubsection{The coastal ephemeral lake model (Coorong model)}

The Coorong model was proposed by Von der Borch et al. (1975), Von der Borch (1976), and Rosen et al. (1989) (see Warren, 2000, for detailed information) to explain the formation of primary and uncemented dolomite in the Coorong lakes of South Australia. The Sr-isotope values (Fig. 12) show that the contribution of ionic solutions, and hence alkalinity, of continental origin to the dolomitizing fluids was minimal, and that the dolomites are seawater derived. This may be distinct from the typical Coorong model, where alkalinity is provided from an inland karst system. But other coastal ephemeral lakes exist, including along the Brazilian coast, north of Rio de Janeiro. Partially unlithified dolomite occurs in Brejo do Espinho (Sánchez-Román et al., 2009), which is largely similar to the Coorong lakes, but ionic solutions are mostly derived from seawater.

A coastal ephemeral lake model would probably be most suitable to explain the homogeneous dolomite beds of the Travenanzes Fm., where hypersaline ponds may have formed in a dryland-river system. However, unlike recent ephemeral lakes (such as Lagoa Vermelha, Brejo do Espinho, and the Coorong lakes) the clay-rich sediment must have inhibited groundwater flow. Hence, while modern coastal ephemeral lakes receive their water largely through seawater percolating through porous dune sand, episodic flooding with seawater must have provided ionic solutions for dolomite formation on a coastal plain.

\subsubsection{A system without a modern analogue}

Overall, the depositional environment reconstructed for the Travenanzes Fm. shows similarities to modern systems where dolomite forms. Among all the modern scenarios, a coastal ephemeral lake model would be most similar to the conditions conducive to homogeneous dolomites, lacking signs of frequent desiccation, while a coastal sabkha model may explain the laminated intervals near the top of the studied succession. In contrast to modern systems, the clayrich sediments of the Travenanzes Fm. preclude any input of groundwater, which plays a role for ionic transport in both the modern-day ephemeral lake model and the different versions of sabkha models. Although modern systems provide valid analogues for the mechanism of dolomite formation in the past, and probably throughout Earth history, none of them is a faithful environmental analogue. The Carnian coastal plains that covered an enormous area along the Tethys margin (Garzanti et al., 1995) represent a system without a single modern analogue in terms of their sedimentary, hydrological, and climatic boundary conditions. Also, the geochemistry of Tethys seawater may have been different from modern sea- water, an issue that requires further investigation (see Burns et al., 2000; Li et al., 2018). These aspects need to be taken into account if we intend to understand the conditions that led to dolomite formation through Earth history.

In the light of the possibility of spontaneous precipitation of fine dolomite mud in the water column, perhaps via formation and aggregation of nanoparticles, further discussion of a nucleation and growth pathway of dolomite is necessary. While several modifiers may also play a role in the water column, such as dissolved organic matter (Frisia et al., 2018), microbial EPS (Bontognali et al., 2013), or suspended clay particles (Liu et al., 2019), fluctuating conditions inducing spontaneous nucleation and growth of dolomite, in agreement with Ostwald's step rule (Deelman, 1999), require further consideration as a factor favourable for dolomite formation on a seasonally variable platform (Meister and Frisia, 2019).

The main finding of this study is that most of the dolomite in the $>100 \mathrm{~m}$ thick Travenanzes Fm. probably formed through direct precipitation from a seawater-derived solution. This mode of primary dolomite formation has rarely been considered in the study of dolostone formations, but may explain the genesis of many other large-scale, finegrained dolomite units that preserve fossils and sedimentary structures.

\section{Conclusions}

Dolomite beds intercalated in a $100 \mathrm{~m}$ thick Carnian alluvial clay sequence in the Travenanzes Fm. largely formed as fine-grained primary mud. The depositional environment during times of dolomite formation most likely prevailed as ephemeral lakes in an extended coastal plain or dryland-river system. The large amounts of clay are related to at least seasonally wet conditions; in addition, palaeosols and diagenetic dolomite nodules could have also formed under such conditions. The facies strongly resembles those of Triassic playa lakes found in the Germanic Basin or in the modern Deep Springs Lake.

$\mathrm{Sr}$ isotopes clearly show a marine signature, indicating seawater as the main source of ions. The depositional environment is most similar to coastal ephemeral lakes resulting in the deposition of homogeneous dolomite beds through most of the sequence, changing into a dirty sabkha near the top of the sequence, where fine dolomite-clay interlayers suggest alternating deposition of extremely fine authigenic dolomite from evaporating water and clay.

Overall, Sr isotopes and petrographic observations provide insight into a system without modern analogue, including elements of both coastal ephemeral lake systems and sabkhas as the environment of primary dolomite formation. Considering the precipitation of primary dolomite from coastal lakes or ponds may help explain other dolomite deposits with pre- 
served primary sedimentary features from throughout geologic history.

Data availability. All data mentioned in the text are in the article or available through the Pangaea data repository (https://doi.org/10.1594/PANGAEA.902276; Rieder et al., 2019).

Supplement. The supplement related to this article is available online at: https://doi.org/10.5194/se-10-1243-2019-supplement.

Author contributions. Fieldwork and sampling were performed by GA, AB, PM, SK, NP, and MR. MH, MR, and WW measured the $\mathrm{Sr}$ isotopes; $\mathrm{SMB}$ provided the $\mathrm{C}$ and $\mathrm{O}$ isotope analyses; $\mathrm{SG}, \mathrm{MR}$, and SK provided the XRD analyses; and PM, MR, and SK performed the petrographic analysis. The concept and idea of the study were developed by PM, NP, and UK. PM and MR primarily wrote the paper. All authors provided comments and corrections for the paper. PM supervised the project.

Competing interests. The authors declare that they have no conflict of interest.

Acknowledgements. We thank Claudia Beybel, Ilka Wünsche, and Leo Slawek for preparing high-quality petrographic thin sections. Thanks also to Wolfgang Obermaier for analysing element concentrations by ICP-OES and Petra Körner for support during TOC measurements. Simon Niebergall provided some of the petrographic images. We furthermore thank Sebastian Viehmann for help during sampling and supervision of the students in the field and Beatrix Bethke for her strong support in the laboratory. Thanks also to Matevz Lorencak for help during the sampling of dolomite from the Coorong Lagoon. We thank Silvia Frisia for input and constructive criticism. We thank Wolfgang Blendinger, Fulvio Franchi, Stephen Lokier, Hans Machel, Chris Romanek, an anonymous reviewer, and the editor Elias Samankassou for constructive comments.

Financial support. This research has been supported by the European Commission, FP7 People: Marie-Curie Actions (project TRIADOL; grant no. 626025) and the University of Vienna.

Review statement. This paper was edited by Elias Samankassou and reviewed by Chris Romanek and one anonymous referee.

\section{References}

Adams, J. E. and Rhodes, M. L.: Dolomitization by seepage refluxion, Am. Assoc. Petrol. Geol. Bull., 44, 1912-
1921, https://doi.org/10.1306/0BDA6263-16BD-11D78645000102C1865D, 1960.

Alderman, A. R. and Skinner, H. C. W.: Dolomite sedimentation in the South-East of South Australia, Am. J. Sci., 255, 561-567, https://doi.org/10.2475/ajs.255.8.561, 1957.

Arp, G., Hoffmann, V.-E., Seppelt, S., and Riegel, W.: Trias und Jura von Göttingen und Umgebung, 74. Jahrestagung der Paläontologischen Gesellschaft, 2-8 October 2004, Exkursion, 6, 147-192, Universitätsdrucke, Göttingen, https://doi.org/10.23689/fidgeo-1790, 2004.

Arp, G., Bielert, F., Hoffmann, V.-E., and Löffler, T.: Palaeoenvironmental significance of lacustrine stromatolites of the Arnstadt Formation ("Steinmergelkeuper", Upper Triassic, N-Germany), Facies, 51, 419-441, https://doi.org/10.1007/s10347-005-00638, 2005.

Baker, P. A. and Burns, S. J.: Occurrence and formation of dolomite in organic-rich continental margin sediments, Am. Assoc. Petrol. Geol. Bull., 69, 1917-1930, https://doi.org/10.1306/948855701704-11D7-8645000102C1865D, 1985.

Balci, N., Menekşe, M., Karagüler, N. G., Sönmez, M. S., and Meister, P.: Reproducing authigenic carbonate precipitation in the hypersaline Lake Acıgöl (Turkey) with microbial cultures, Geomicrobiol. J., 33, 758-773, https://doi.org/10.1080/01490451.2015.1099763, 2016.

Bontognali, T. R. R., Vasconcelos, C., Warthmann, R. J., Bernasconi, S. M., Dupraz, C., Strohmenger, C. J., and McKenzie, J. A.: Dolomite formation within microbial mats in the coastal sabkha of Abu Dhabi (United Arab Emirates), Sedimentology, 57, 824-844, https://doi.org/10.1111/j.13653091.2009.01121.x, 2010.

Bontognali, T. R. R., McKenzie, J. A., Warthmann, R., and Vasconcelos, C.: Microbially influenced formation of $\mathrm{Mg}$-calcite and Ca-dolomite in the presence of exopolymeric substances produced by sulphate-reducing bacteria, Terra Nova, 26, 72-77, https://doi.org/10.1111/ter.12072, 2013.

Bouton, A., Vennin, E., Pace, A., Bourillot, R., Dupraz, C., Thomazo, C., Brayard, A., Désaubliaux, G., and Visscher, P. T.: External controls on the distribution, fabrics and mineralization of modern microbial mats in a coastal hypersaline lagoon, Cayo Coco (Cuba), Sedimentology, 63, 972-1016, https://doi.org/10.1111/sed.12246, 2016.

Brack, P., Mundil, R., Oberli, F., Meier, M., and Rieber, H.: Biostratigraphic and radiometric age data question the Milankovitch characteristics of the Latemar cycles (Southern Alps, Italy), Geology, 24, 371-375, https://doi.org/10.1130/00917613(1996)024<0371:BARADQ>2.3.CO;2, 1996.

Brack, P., Rieber, H., and Urlichs, M.: Pelagic successions in the Southern Alps and their correlation with the Germanic Middle Triassic, Zentralbl. Geol. Paläontol. Teil I, 7-8, 853-876, 1999.

Breda, A. and Preto, N.: Anatomy of an Upper Triassic continental to marginal-marine system: the mixed siliciclasticcarbonate Travenanzes Formation (Dolomites, Northern Italy), Sedimentology, 58, 1613-1647, https://doi.org/10.1111/j.13653091.2011.01227.x, 2011.

Breitenbach, S. F. M. and Bernasconi, S. M.: Carbon and oxygen isotope analysis of small carbonate samples (20 to $100 \mu \mathrm{g}$ ) with a GasBench II preparation device, Rapid Commun. Mass Spectrom., 25, 1910-1914, https://doi.org/10.1002/rcm.5052, 2011. 
Burns, S. J., McKenzie, J. A., and Vasconcelos, C.: Dolomite formation and biogeochemical cycles in the Phanerozoic, Sedimentology, 47, 49-61, https://doi.org/10.1046/j.13653091.2000.00004.x, 2000.

Chilingar, G. V.: Relationship between $\mathrm{Ca} / \mathrm{Mg}$ ratio and geological age, AAPG Bull., 40, 22562266, https://doi.org/10.1306/5CEAE577-16BB-11D78645000102C1865D, 1956.

Clayton, R. N., Jones, B. F., and Berner, R. A.: Isotope studies of dolomite formation under sedimentary conditions, Geochim. Cosmochim. Ac., 32, 415-432, https://doi.org/10.1016/00167037(68)90076-8, 1968.

Cleveland, D. M., Nordt, L. C., and Atchley, S. C.: Paleosols, trace fossils, and precipitation estimates of the uppermost Triassic strata in northern New Mexico, Palaeogeogr. Palaeocl., 257, 421444, https://doi.org/10.1016/j.palaeo.2007.09.023, 2008.

Court, W. M., Paul, A., and Lokier, S. W.: The preservation potential of environmentally diagnostic sedimentary structures from a coastal sabkha, Mar. Geol., 386, 1-18, https://doi.org/10.1016/j.margeo.2017.02.003, 2017.

Czurda, K. and Nicklas, L.: Zur Mikrofazies und Mikrostratigraphie des Hauptdolomites und des Plattenkalk-Niveaus der Klostertaler Alpen und des Rhätikon (Nördliche Kalkalpen, Vorarlberg), in: Festband 300 Jahre, Geol. Inst. Univ. Innsbruck, pp. 165-253, 1970.

Dal Corso, J., Mietto, P., Newton, R. J., Pancost, R. D., Preto, N., Roghi, G., and Wignall, P. B.: Discovery of a major negative $\delta^{13} \mathrm{C}$ spike in the Carnian (Late Triassic) linked to the eruption of Wrangellia flood basalts, Geology, 40, 79-82, https://doi.org/10.1130/G32473.1, 2012.

Deelman, J. C.: Low-temperature nucleation of magnesite and dolomite, Neues Jahrbuch für Mineralogie (Stuttgart), Monatshefte, 7, 289-302, 1999.

Demicco, R. V. and Hardie, L. A.: Sedimentary structures and early diagenetic features of shallow marine carbonate deposits, SEPM Atlas, Ser., 1, 265, 1994.

DePaolo, D. J. and Ingram, B.: High-resolution stratigraphy with strontium isotopes, Science, 227, 938-941, https://doi.org/10.1126/science.227.4689.938, 1985.

De Zanche, V., Gianolla, P., Mietto, P., Siorpaes, C., and Vail, P. R.: Triassic sequence stratigraphy in the Dolomites (Italy), Sci. Geol. Mem., 45, 1-27, 1993.

Doglioni, C.: Tectonics of the Dolomites (Southern Alps-Northern Italy), J. Struct. Geol., 9, 181-193, https://doi.org/10.1016/01918141(87)90024-1, 1987.

Eugster, H. P. and Hardie, L. A.: Saline lakes, in: Lakes, Chemistry, Geology, Physics, edited by: Lerman, A., Springer-Verlag, New York, NY, pp. 237-293, 1978.

Eugster, H. P. and Surdam, R. C.: Depositional environment of the Green River Formation of Wyoming: a preliminary report, Bull. Geol. Soc. Am., 84, 1115-1120, https://doi.org/10.1130/00167606(1973)84<1115:DEOTGR>2.0.CO;2, 1973.

Fischer, A. G.: The Lofer cyclothems of the Alpine Triassic, Kansas Geol. Surv. Bull., 169, 107-149, 1964.

Flügel, E.: Microfacies of carbonate rocks - analysis, interpretation and application, 2nd edn., Springer-Verlag, Berlin Heidelberg, ISBN 978-3-642-03796-2, 2010.

Frisia, S.: Mechanisms of complete dolomitization in a carbonate shelf: comparison between the Norian Dolomia Principale
(Italy) and the Holocene of Abu Dhabi Sabkha, in: A volume in honour of Dolomieu, edited by: Purser, B., Tucker, M., and Zenger, D., Spec. Publs. Int. Ass. Sediment., 21, 55-74, https://doi.org/10.1002/9781444304077.ch5, 1994.

Frisia, S. and Wenk, H.-R.: TEM and AEM study of pervasive, multi-step dolomitization of the upper Triassic Dolomia Principale (Northern Italy), J. Sed. Petrol., 63, 1049-1058, https://doi.org/10.1306/D4267C94-2B26-11D78648000102C1865D, 1993.

Frisia, S., Borsato, A., and Hellstrom, J.: High spatial resolution investigation of nucleation, growth and early diagenesis in speleothems as exemplar for sedimentary carbonates, Earth-Sci. Rev., 178, 68-91, 2018.

Füchtbauer, H. and Goldschmidt, H.: Beziehungen zwischen Calzium-Gehalt und Bildungsbedingungen der Dolomite, Geologische Rundschau, 55, 29-40, 1966.

Garzanti, E., Gnaccolini, M., and Jadoul, F.: Anatomy of a semiarid coastal system: the Upper Carnian of Lombardy (Italy), Riv. Ital. Paleontol. Stratigr., 101, 17-36, https://doi.org/10.13130/20394942/8563, 1995.

Gattolin, G., Breda, A., and Preto, N.: Demise of Late Triassic carbonate platforms triggered the onset of a tide-dominated depositional system in the Dolomites, Northern Italy, Sediment. Geol., 297, 38-49, https://doi.org/10.1016/j.sedgeo.2013.09.005, 2013.

Gattolin, G., Preto, N., Breda, A., Franceschi, M., Isottona, M., and Gianolla P.: Sequence stratigraphy after the demise of a high-relief carbonate platform (Carnian of the Dolomites): Sealevel and climate disentangled, Palaeogeogr. Palaeocl., 423, 117, https://doi.org/10.1016/j.palaeo.2015.01.017, 2015.

Gianolla, P., De Zanche, V., and Mietto, P.: Triassic sequence stratigraphy in the Southern Alps (Northern Italy): definition of sequences and basin evolution, in: Mesozoic and Cenozoic Sequence Stratigraphy of European Basins, edited by: deGraciansky, P.-C., Hardenbol, J., Jacquin, T., and Vail, P. R., SEPM Spec. Publ., 60, 719-747, https://doi.org/10.2110/pec.98.02.0719, 1998.

Ginsburg, R. N.: Landward movement of carbonate mud: new model for regressive cycles in carbonates (abs.), AAPG Bull., $55,340,1971$.

Given, R. K. and Wilkinson, B. H.: Dolomite abundance and stratigraphic age; constraints on rates and mechanisms of Phanerozoic dolostone formation, J. Sediment. Res., 57, 1068-1078, https://doi.org/10.1306/212F8CF1-2B24-11D78648000102C1865D, 1987.

Gregg, J. M., Bish, D. L., Kaczmarek, S. E., and Machel, H. G.: Mineralogy, nucleation and growth of dolomite in the laboratory and sedimentary environment: A review, Sedimentology, 62, 1749-1769, https://doi.org/10.1111/sed.12202, 2015.

Handy, M. R., Schmid, S. S., Bousquet, R., Kissling, E., and Bernoulli, D.: Recoiling plate-tectonic reconstructions of Alpine Tethys with the geological-geophysical record of spreading and subduction in the Alps, Earth-Sci. Rev., 102, 121-158, https://doi.org/10.1016/j.earscirev.2010.06.002, 2010.

Hill Jr., W. E. and Evans, D. R.: Solubility of twenty minerals in selected versene (EDTA) solutions, State Geological Survey Kansas, Bull. 175, pp. 22, available at: http://www. kgs.ku.edu/Publications/Bulletins/175_3/index.html (last access: 24 July 2019), 1965. 
Hsü, K. J. and Schneider, J.: Progress report on dolomitization hydrology of Abu Dhabi Sabkhas, Arabian Gulf, The Persian Gulf, Springer, New York, 409-422, https://doi.org/10.1007/9783-642-65545-6_20, 1973.

Hsü, K. J. and Siegenthaler, C.: Preliminary experiments on hydrodynamic movement induced by evaporation and their bearing on the dolomite problem, Sedimentology, 12, 11-25, https://doi.org/10.1111/j.1365-3091.1969.tb00161.x, 1969.

Iannace, A. and Frisia, S.: Changing dolomitization styles from Norian to Rhaetian in southern Tethys realm, in: A Volume in Honour of Dolomieu, edited by: Purser, B., Tucker, M., and Zenger, D., Int. Assoc. Sedimentol. Spec. Publ., 21, 75-89, https://doi.org/10.1002/9781444304077.ch6, 1994.

Illing, L. V., Wells, A. J., and Taylor, J. C. M.: Penecontemporary dolomite in the Persian Gulf, in: Dolomitization and limestone diagenesis, edited by: Pray, L. C. and Murray, L. C., SEPM Spec. Publ., 13, 89-111, https://doi.org/10.2110/pec.65.07.0089, 1965.

Jones, B. F.: The hydrology and mineralogy of Deep Springs Lake, Inyo County, California, US Geol. Surv. Prof. Paper, 502-A, 56, https://doi.org/10.3133/pp502A, 1965.

Korte, C., Kozur, H. W., Bruckschen, P., and Veizer, J.: Strontium isotope evolution of Late Permian and Triassic seawater, Geochim. Cosmochim. Ac., 67, 47-62, https://doi.org/10.1016/S0016-7037(02)01035-9, 2003.

Kraus, O.: Die Raibler Schichten des Drauzuges (Südliche Kalkalpen), Lithofazielle, sedimentpetrographische und paläogeographische Untersuchungen, Jb. Geol. B.-A., 112, 81-152, 1969.

Land, L. S.: Failure to precipitate dolomite at $25^{\circ} \mathrm{C}$ from dilute solution despite 1000-fold oversaturation after 32 years, Aquat. Geochem., 4, 361-368, https://doi.org/10.1023/A:1009688315854, 1998.

Last, W. M.: Lacustrine dolomite - an overview of modern, Holocene, and Pleistocene occurrences, Earth-Sci. Rev., 27, 221263, https://doi.org/10.1016/0012-8252(90)90004-F, 1990.

Li, M., Song, H., Algeo, T. J., Wignall, P. B., Dai, X., and Woods, A. D.: A dolomitization event at the oceanic chemocline during the Permian-Triassic transition, Geology, 46, 1043-1046, https://doi.org/10.1130/G45479.1, 2018.

Liu, D., Xu, Y., Papineau, D., Yub, N., Fan, Q., Qiu, X., and Wang, H.: Experimental evidence for abiotic formation of low-temperature proto-dolomite facilitated by clay minerals, Geochim. Cosmochim. Ac., 247, 83-95, https://doi.org/10.1016/j.gca.2018.12.036, 2019.

Lumsden, D. N.: Discrepancy between thin-section and Xray estimates of dolomite in limestone, J. Sed. Petrol., 49, 429-435, https://doi.org/10.1306/212F7761-2B24-11D78648000102C1865D, 1979.

Machel, H. G.: Concepts and models of dolomitization: a critical reappraisal. Geological Society, London, Special Publications, 235, 7-63, https://doi.org/10.1144/GSL.SP.2004.235.01.02, 2004.

Mather, C. C., Skrzypek, G., Dogramaci, S., and Grierson, P. F.: Paleoenvironmental and paleohydrochemical conditions of dolomite formation within a saline wetland in arid northwest Australia, Quat. Sci. Rev., 185, 172-188, https://doi.org/10.1016/j.quascirev.2018.02.007, 2018.

McArthur, J. M., Howarth, R. J., and Shield, G. A.: Strontium isotope stratigraphy. The geologic time scale, 2012, edited by:
Gradstein, F. M., Ogg, J. G., Schmotz, M. D., and Ogg, G. M., Elsevier, UK, the Netherklands, USA, 1 of 2, 1144 pp., https://doi.org/10.1017/CBO9780511536045.008, 2012.

McCormack, J., Bontognali, T. R. R., Immenhauser, A., and Kwiecien, O.: Controls on cyclic formation of Quaternary early diagenetic dolomite, Geophys. Res. Lett., 45, 3625-3634, https://doi.org/10.1002/2018GL077344, 2018.

McKenzie, J.: Holocene dolomitzation of calcium carbonate sediments from the coastal sabkhas of Abu Dhabi, U.A.E., J. Geol., 89, 185-198, https://doi.org/10.1086/628579, 1981.

McKenzie, J., Hsü, K. J., and Schneider, J. F.: Movement of subsurface waters under the sabkha, Abu Dhabi, UAE and its relation to evaporative dolomite genesis, Spec. Publ.-SEPM, 28, 11-30, https://doi.org/10.2110/pec.80.28.0011, 1980.

Meister, P., Bernasconi, S., McKenzie, J. A., Vasconcelos, C., Frank, M., Gutjahr, M., and Schrag, D.: Dolomite formation in the dynamic deep biosphere: Results from the Peru Margin (ODP Leg 201), Sedimentology, 54, 1007-1032, https://doi.org/10.1111/j.1365-3091.2007.00870.x, 2007.

Meister, P., Reyes, C., Beaumont, W., Rincon, M., Collins, L., Berelson, W., Stott, L., Corsetti, F., and Nealson, K. H.: Calcium- and magnesium-limited dolomite precipitation at Deep Springs Lake, California, Sedimentology, 58, 1810-1830, https://doi.org/10.1111/j.1365-3091.2011.01240.x, 2011.

Meister, P., McKenzie, J. A., Bernasconi, S. M., and Brack, P.: Dolomite formation in the shallow seas of the Alpine Triassic, Sedimentology, 60, 270-291, https://doi.org/10.1111/sed.12001, 2013.

Meister, P. and Frisia, S.: Dolomite formation by nanocrystal aggregation in the Dolomia Principale of the Brenta Dolomites (northern Italy), Rivista Italiana di Stratigrafia e Paleontologia, 125, 183-196, https://doi.org/10.13130/2039-4942/11297, 2019.

Missana, T., Garcia-Gutierrez, M., and Alonso, U.: Sorption of strontium onto illite/smectite mixed clays, Phys. Chem. Earth, 33, 156-162, https://doi.org/10.1016/j.pce.2008.10.020, 2008.

Moore, D. M. and Reynolds, R. C.: X-ray diffraction and the identification and analysis of clay minerals, Oxford University Press, New York, 378 p, ISBN 0.19.505170.X, 1997.

Müller, D. W., McKenzie, J. A., and Mueller, P. A.: Abu Dhabi sabkha, Persian Gulf, revisited: application of strontium isotopes to test an early dolomitization model, Geology, 18, 618-621, https://doi.org/10.1130/00917613(1990)018<0618:ADSPGR>2.3.CO;2, 1990a.

Müller, D. W., Mueller, P. A., and McKenzie, J. A.: Strontium isotopic ratios as fluid tracers in Messinian evaporites of the Tyrrhenian Sea (western Mediterranean Sea), in: Proc. ODP, Sci. Results, edited by: Kastens, K. A., Mascle, J., et al., 107, College Station, TX (Ocean Drilling Program), 603-614, https://doi.org/10.2973/odp.proc.sr.107.194.1990, 1990b.

Muttoni, G., Kent, D. V., Garzanti, E., Brack, P., Abrahamsen, N., and Gaetani, M.: Early Permian Pangea 'B' to Late Permian Pangea 'A', Earth Planet. Sci. Lett., 215, 379-394, https://doi.org/10.1016/S0012-821X(03)00452-7, 2003.

Neri, C., Gianolla, P., Furlanis, S., Caputo, R., and Bosellini, A.: Note illustrative della Carta Geologica d'Italia alla scala 1: 50.000, Foglio 029 Cortina d'Ampezzo, A.P.A.T. System Cart, Roma, 200 pp., 2007. 
Neuhuber, S., Steier, P., Gier, S., Draganits, E., and Kogelbauer, I.: Radiogenic Carbon Isotopes in Authigenic Carbonate from Lake Neusiedl, Austria, Geophys. Res. Abstr., 17, 15399, 2015.

Neumann, W. and Huster, E.: The half-life of ${ }^{87} \mathrm{Rb}$ measured as difference between the isotopes ${ }^{87} \mathrm{Rb}$ and ${ }^{85} \mathrm{Rb}$, Zeitschrift für Physik, 270, 121-127, https://doi.org/10.1007/BF01677443, 1974.

Ogg, J. G.: Triassic, in: The geologic time scale 2012, edited by: Gradstein, F. M., Ogg, J. G., Schmitz, M., and Ogg, G., Elsevier, Cambridge University Press, Cambridge, 681-730, 2012.

Perri, E., Tucker, M. E., Słowakiewicz, M., Whitaker, F., Bowen, L., and Perrotta, I. D.: Carbonate and silicate biomineralization in a hypersaline microbial mat (Mesaieed sabkha, Qatar): Roles of bacteria, extracellular polymeric substances and viruses, Sedimentology, 65, 1213-1245, https://doi.org/10.1111/sed.12419, 2018.

Peterson, M. N. A., Bien, G. S., and Berner, R. A.: Radiocarbon studies of recent dolomite from Deep Springs Lake, California. J. Geophys. Res., 68, 6493-6505, https://doi.org/10.1029/JZ068i024p06493, 1963.

Preto, N. and Hinnov, L. A.: Unravelling the origin of shallow-water cyclothems in the Upper Triassic Dürrenstein Formation (Dolomites, Italy), J. Sed. Res., 73, 774-789, https://doi.org/10.1306/030503730774, 2003.

Preto, N., Breda, A., Corso, J. D., Spötl, C., Zorzi, F., and Frisia, S.: Primary dolomite in the Late Triassic Travenanzes Formation, dolomites, Northern Italy: facies control and possible bacterial influence, Sedimentology, 62, 697-716, https://doi.org/10.1111/sed.12157, 2015.

Randazzo, A. F. and Zachos, L. G.: Classification and description of dolomitic fabrics of rocks from the Floridan aquifer, USA Sediment. Geol., 37, 151-162, https://doi.org/10.1016/00370738(84)90005-8, 1983.

Ratschbacher, L., Merle, O., Davy, P., and Cobbold, P.: Lateral extrusion in the Eastern Alps, Part 1: Boundary conditions and experiments scaled for gravity, Tectonics, 10, 245-256, https://doi.org/10.1029/90TC02622, 1991.

Reinhardt, L. and Ricken, W.: The stratigraphic and geochemical record of Playa Cycles: monitoring a Pangaean monsoonlike system (Triassic, Middle Keuper, S. Germany), Palaeogeogr. Palaeocl., 161, 205-227, https://doi.org/10.1016/S00310182(00)00124-3, 2000.

Rieder, M., Wegner, W., Horschinegg, M., Klackl, S., Preto, N., Breda, A., Gier, S., Klötzli, U., Bernasconi, S. M., Arp, G., and Meister, P.: Strontium, carbon, and oxygen isotopes in Triassic dolomites - Travenanzes Formation (Italy), PANGAEA, https://doi.org/10.1594/PANGAEA.902276, 2019.

Rodriguez-Blanco, J. D., Shaw, S., and Benning, L. G.: A route for the direct crystallization of dolomite, Am. Mineral., 100, 11721181, https://doi.org/10.2138/am-2015-4963, 2015.

Rosen, M. R., Miser, D. E., Starcher, M. A., and Warren, J. K.: Formation of dolomite in the Coorong region, South Australia, Geochim. Cosmochim. Ac., 53, 661-669, https://doi.org/10.1016/0016-7037(89)90009-4, 1989.

Rosenbaum, J. and Sheppard, S. M.: An isotopic study of siderites, dolomites and ankerites at high temperatures, Geochim. Cosmochim. Ac., 50, 1147-1150, https://doi.org/10.1016/00167037(86)90396-0, 1986.
Russo, F., Neri, C., Mastandrea, A., and Baracca, A.: The mud mound nature of the Cassian Platform Margins of the Dolomites A case history: the Cipit boulders from Punta Grohmann (Sasso Piatto Massif, northern Italy), Facies, 36, 2536, https://doi.org/10.1007/BF02536875, 1997.

Sánchez-Román, M., Vasconcelos, C., Warthmann, R., Rivadeneyra, M. A., and McKenzie, J. A.: Microbial dolomite precipitation under aerobic conditions: results from Brejo do Espinho Lagoon (Brazil) and culture experiments, Int. Assoc. Sediment. Spec. Publ., 40, 167-178, https://doi.org/10.1002/9781444312065.ch11, 2009.

Sánchez-Román, M., McKenzie, J. A., Rebello Wagener, A., Romanek, C. S., Sánchez-Navas, A., and Vasconcelos, C.: Experimentally determined biomediated $\mathrm{Sr}$ partition coefficient for dolomite: Significance and implication for natural dolomite, Geochim. Cosmochim. Ac., 75, 887-904, https://doi.org/10.1016/j.gca.2010.11.015, 2011.

Seegis, D.: Die Lehrbergschichten im Mittleren Keuper von Süddeutschland: Stratigraphie, Petrographie, Paläontologie, Genese, Hennecke, Remshalden, 382 pp., 1997.

Sheldon, N. D.: Do red beds indicate paleoclimatic conditions?: A Permian case study. Palaeogeogr. Palaeocl., 228, 305-319, 2005.

Stampfli, G. M. and Borel, G. D.: A plate tectonic model for the Paleozoic and Mesozoic constrained by dynamic plate boundaries and restored synthetic oceanic isochrons, Earth Planet. Sci. Lett., 196, 17-33, https://doi.org/10.1016/S0012-821X(01)00588-X, 2002.

Teal, C. S., Mazzullo, S. J., and Bischoff, W. D.: Dolomitization of Holocene shallow-marine deposits mediated by sulfate reduction and methanogenesis in normalsalinity seawater, northern Belize, J. Sediment. Res., 70, 649-663, https://doi.org/10.1306/2DC4092E-0E47-11D78643000102C1865D, 2000.

Vahrenkamp, V. C. and Swart, P. K.: New distribution coefficient for the incorporation of strontium into dolomite and its implications for the formation of ancient dolomites, Geology, 18, 387-391, https://doi.org/10.1130/00917613(1990)018<0387:NDCFTI>2.3.CO;2, 1990.

Van Tuyl, F. M.: The origin of dolomite, Annual Report 1914, Iowa Geological Survey, XXV, 257-421, 1914.

Vasconcelos, C., McKenzie, J. A., Warthmann, R., and Bernasconi, S.: Calibration of the $\delta^{18} \mathrm{O}$ paleo-thermometer with dolomite formed in microbial cultures and natural environments, Geology, 33, 317-320, https://doi.org/10.1130/G20992.1, 2005.

Vasconcelos, C., Warthmann, R., McKenzie, J. A., Visscher, P. T., Bittermann, A. G., and van Lith, Y.: Lithifying microbial mats in Lagoa Vermelha, Brazil: Modern Precambrian relics?, Sediment. Geol., 185, 175-183, https://doi.org/10.1016/j.sedgeo.2005.12.022, 2006.

Veizer, J., Ala, D., Azmy, K., Bruckschen, P., Buhl, D., Bruhn, F., Carden, G. A. F., Diener, A., Ebneth, S., Godderis, Y., Jasper, T., Korte, C., Pawellek, F., Podlaha, O. G., and Strauss, H.: ${ }^{87} \mathrm{Sr} /{ }^{86} \mathrm{Sr}, \delta^{13} \mathrm{C}$ and $\delta^{18} \mathrm{O}$ evolution of Phanerozoic seawater, Chem. Geol., 161, 59-88, https://doi.org/10.1016/S00092541(99)00081-9, 1999.

Von der Borch, C. C.: Stratigraphy and formation of Holocene dolomitic carbonate deposits of the Coorong area, South Australia, J. Sediment. Res., 46, 952- 
966, https://doi.org/10.1306/212F709F-2B24-11D78648000102C1865D, 1976.

Von der Borch, C. C., Lock, D. E., and Schwebel, D.: Groundwater formation of dolomite in the Coorong region of South Australia, Geology, 3, 283-285, https://doi.org/10.1130/00917613(1975)3<283:GFODIT>2.0.CO;2, 1975.

Warren, J.: Sedimentology and mineralogy of dolomitic Coorong Lakes, South Australia, J. Sediment. Petrol., 60, 843-858, https://doi.org/10.1306/212F929B-2B24-11D78648000102C1865D, 1990.
Warren, J.: Dolomite: occurrence, evolution and economically important associations, Earth-Sci. Rev., 52, 1-81, https://doi.org/10.1016/S0012-8252(00)00022-2, 2000.

Wenk, H. R., Meisheng, H., and Frisia, S.: Partially disordered dolomite: microstructural characterization of Abu Dhabi sabkha carbonates, Am. Mineral., 78, 769-774, 1993. 